\title{
Mülkiyet Kavramının Erken Çocuklukta Gelişim Sürreci ve Farklı Boyutları
}

\section{A Review of Ownership: The Developmental Course and Its Dimensions}

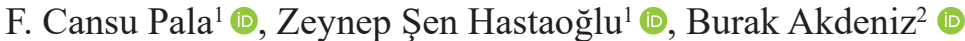

${ }^{1}$ Ege Üniversitesi, Edebiyat Fakültesi, Psikoloji Bölümü, İzmir-Türkiye

${ }^{2}$ İstanbul Aydın Üniversitesi, Fen-Edebiyat Fakültesi, Psikoloji Bölümü, İstanbul-Türkiye

ORCID: F.C.P. 0000-0001-8489-4870;

Z.Ş.H. 0000-0003-1615-0129;

B.A. $0000-0002-5113-3191$

Sorumlu yazar/Corresponding author:

F. Cansu Pala,

Ege Üniversitesi, Edebiyat Fakültesi, Psikoloji

Bölümü, İzmir-Türkiye

E-posta/E-mail: cansu.pala@ege.edu.tr

Başvuru/Submitted: 20.03.2020

Kabul/Accepted: 31.12 .2020

Online Yayın/Published Online: 10.08.2021

Citation/Atıf: Pala, F.C., Sen Hastaoglu, Z., Akdeniz, B. (2021). Mülkiyet Kavramının Erken Çocuklukta Gelişim Süreci ve Farkl Boyutları. Psikoloji Çalışmaları - Studies in Psychology, 41(2), 365-401. https://doi.org/10.26650/SP2020-0034
ÖZ

Mülkiyet, bir kişi ile nesne arasında kurulan ve diğer insanlarca kabul edilen bir aitlik ilişkisidir. Bir nesnenin kime ait olduğunun bilmek, erken çocukluk döneminde çocuğun 'benim' ve 'benim olmayan'1 ayırt etmesini sağlar. Bu derleme çalışması, erken çocukluk döneminde mülkiyet kavramının gelişim süreçlerini, kavramın temel boyutlarını ve mülkiyet gelişiminin dil ve kültür ile olan ilişkisini ele almayı amaçlamaktadır. Mülkiyetin çok boyutlu yapısı hangi tür nesnelerin sahiplenildiğini, mülkiyet kararının nasıl verildiğini, mülkiyetle gelen hak ve ayrıcalıkların nasıl aktarıldığını içerir. İki yaşındaki çocukların çoğu, bir nesnenin kime ait olduğunu tanıyabilir ve mülkiyeti belirleyebilirken, ancak beşinci yaş günlerinden sonra çocuklar, bir nesnenin sahibini arzuya göre değil, transfer kurallarına göre belirleyebilir. Mülkiyetteki gelişimsel farklılıkları raporlayan çalışmalarda yaşın etkisinin tutarsız olduğu göze çarpmaktadır. Nesne ve birey arasında kurulan soyut bir ilişkinin çocuk tarafından anlaşılmasını ve bu ilişkinin zihinde temsil edilebilmesini gerektirdiği için mülkiyet kavramının, erken çocukluk döneminde hızla değişim gösteren sosyal bilişsel süreçler kapsamında ele alınması gerektiği öne sürülmüştür. Bu nedenle, bu derleme çalışmasında benlik gelişimi, zihinsel temsil ve diğer bilişsel becerilerin mülkiyetin altında yatan etmenlerden olup olmayacağı tartışılmıştır. Ayrıca, dil ve kültürün hem doğrudan hem bilişsel yapılar aracılığı ile, mülkiyet kavramına olan olası etkilerinden de bahsedilmiştir. Uluslararası alan yazında varlığı tanınsa da, gelişimi ve onu oluşturan öğeler yeterince incelenmeyen mülkiyet kavramı, hem sosyal bir yapı oluşu hem de bilişsel becerilerin üstüne inşa edildiği düşüncesi bakımından oldukça ilgi çekicidir. İnsanın sahiplik anlayışına yüklediği anlamın kavranmasının ve sahip olduğu nesneler üzerinden yaptığı anlam arayışının (genişletilmiş benlik hipotezi) incelenmesinin, mülkiyet kavramının nasıl bir gelişimsel örüntüyü takip ettiğinin anlaşılması sayesinde aydınlatılması ümit edilmektedir. Türkiye örnekleminde bu kavramı ele alan bir çalışmanın henüz bulunmuyor olması nedeniyle; bilinen gelişimsel özellikleri ve temel yapılarına değinilen mülkiyet kavramının bu derlemede alandaki araştırmacılara tanıtılması amaçlanmaktadır.

Anahtar Kelimeler: Mülkiyet, mülkiyet aktarımı, mülkiyet hakları, erken çocukluk dönemi, gelişim, sosyal bilişsel süreçler 


\section{ABSTRACT}

Ownership is a relation of belonging between a person and an object that is accepted by other people. Knowing to whom an object belongs allows children to differentiate between what is theirs and what is not. This review aims to explore the development processes of ownership during early childhood, the basic dimensions of the concept of ownership, and the relationship of ownership development with language and culture. The multidimensional structure of ownership includes the kinds of objects that are owned, how ownership decisions are made, and how property rights and privileges are transferred. Most two-year-olds can recognize who owns an object and determine ownership, but only after the fifth birthday can children determine an owner not by desire but by transfer rules. In studies reporting developmental differences in ownership, the effect of age is strikingly inconsistent. However, ownership should be addressed in early childhood within the scope of rapidly changing social cognitive processes. A child needs to understand the abstract relationship between an object and an individual and represent that relationship in their mind. Therefore, this review study discusses whether self-development, mental representation, and other cognitive abilities are among the underlying factors of ownership. In addition, the possible effects of language and culture on ownership, both directly and cognitively, are also mentioned. Although ownership is exciting in social structure and in built-upon cognitive skills recognized in the literature, its development and constituent elements have yet to be examined sufficiently. Understanding ownership's developmental pattern might illuminate meaning attributed to ownership and objects (extended-self hypothesis). Since no research has addressed this concept in a Turkish sample to date, this review aims to introduce the notion of ownership, its developmental characteristics, and its basic structures for researchers in the field.

Keywords: Ownership, ownership transfer, ownership rights, early childhood, development, social cognitive processes

\section{EXTENDED ABSTRACT}

Ownership is an abstract connection between a person and an object that grants some rights (Blake \& Harris, 2011). Toward the end of the first year of life, infants begin to react when another person takes toys away from them (Ross, 1996). This reaction can signal ownership; however, it could also be a response to an interruption of an enjoyable activity.

Understanding ownership development requires an in-depth examination of certain constructs: the sense of self, mental representation, and the comprehension of objectperson relationships (Blake \& Harris, 2011). The influence of the sense of self on ownership can be observed with 18-28-month-old infants who pass the self-recognition task (Fasig, 2000). Fasig also reported that knowledge of the extended self relates to comprehending possession.

Moreover, children use their personal experiences with objects to understand ownership (Noles \& Keil, 2011), and ownership development could be defined by an inherent bias toward possession, for instance, having a unique relationship with an object (Blake \& Harris, 2011). Ownership is a multifaceted construct, with various unresolved issues surrounding it: whether an object is owned or not, what types of objects are owned, how ownership is established, how it is transferred, who can be an owner, and what the ownership rights are. 
Many things in daily life, such as objects, ideas, living beings (as pets), and lands, can be owned. The diversity of these assets elicits judgment about whether an object is owned. Compared to natural objects (e.g., a tree; Neary, Van de Vondervoort, \& Friedman, 2012), children expected human-made objects (artifacts; e.g., a book) to have an owner, using physical and verbal cues to decide who the owner is. Verbal cues are more helpful than physical cues, which are inadequate to explain ownership associations, because verbalizing can clarify confusion (Blake et al., 2012; Gelman, 2009; Harris \& Koenig, 2006). By age four, children prioritize verbal over physical cues, considering them more reliable information. Recent studies (e.g., Malcolm et al., 2014; Neary, Friedman, \& Burnstein, 2009) have demonstrated that both children and adults use gender and age stereotypes in judging ownership (who owns an object). When a conflict arises between one's desires and ownership rights, young children assume that one would behave according to desire and ignore ownership rights (e.g., Pesowski \& Friedman, 2018; Pietraszewski \& Shaw, 2015).

Although ownership is usually gained through legitimate transfers from one person to another (e.g., a gift), illegitimate transfers do occur (e.g., stealing; Kanngiesser \& Hood, 2014a). The comprehension of the discrepancy between these transfers might follow different developmental pathways and indicate diverse cognitive loads. The comprehension of ownership transfer for abstractions, such as ideas, is more complicated than for material objects. Five-year-olds make negative attributions to a person who copies others' works of art, whereas younger children cannot make this distinction.

Owner privilege is another issue; three-year-olds begin to understand normative rules, but two-year-olds also defend their ownership rights (Dunn \& Munn, 1987; Rossano et al., 2011). Comprehending ownership is inseparable from prosocial behaviors because children who understand the transfer of ownership tend to share more. The critical role of culture and language in ownership development is another issue included in this review (Yang et al., 2014), particularly because it might interlink with underlying cognitive domains. Moreover, comparing Eastern and Western cultures might explain the different aspects of ownership development, such as labor or legal possession. The measurement of ownership relies heavily on linguistic ability, which might be a confounding variable. This review aims to introduce the multilayered nature of ownership development during early childhood along with its potential relationship to other social and cognitive abilities.

\section{Discussion}

Although few studies have been conducted on ownership development, interest in the topic is growing. In their seminal paper, Blake and Harris (2011, p. 40) proposed that "instead 
of relying on permanent and concrete ownership indicators, ownership information must be coded through mental representations to accept, track, and update the relationship between owner and owned." This quotation is critical for revealing the construct's cognitive underpinnings. Over age three, children begin to identify the person who decides whether others can use an object as that object's owner. In early childhood, rapid changes in social and cognitive abilities make it impossible to consider ownership without these abilities. 
Mülkiyet (ownership), bir kişi ile diğer varlıklar arasında kurulan ve diğer insanlarca onaylanan 'aitlik ilişkisi’ anlamına gelmektedir (Blake ve Harris, 2011). Nesnenin soyut bir niteliği olan mülkiyet, sosyal ve normatif biçimde tanımlanmaktadır (Blake ve Harris, 2011; Friedman ve Neary, 2008). Çocukların mülkiyeti ne zaman kavradığı, hangi nesnelerin sahiplenildiği, nesnenin sahibine dair çıkarımların ne zaman yapıldığı ve bu kavramın gelişiminde etkili diğer bilişsel özelliklerin neler olduğu soruları son yıllarda araştırmacıların ilgisini çekmektedir. Bazı araştırmacılara göre mülkiyet, sosyal yaşamda önemli etkilere sahip, günlük yaşama dair mantıksal çıkarımlarda bulunmayı gerektiren üst-düzey bir bilişsel beceri (Friedman ve Ross, 2011) olması sebebiyle, insanları diğer türlerden ayıran evrensel özelliklerden biridir (Blake ve Harris, 2011; Boyer, 2015; Nancekivell, Friedman ve Gelman, 2019). Nesneye sahip olan kişi öncelikle bu nesneyi zihninde temsil edebilmeli, daha sonra bu nesne ile kendisi arasındaki ilişkiyi aklında tutabilmeli, sahip olduğu nesneleri belleğinde depolayabilmelidir (Blake ve Harris, 2011; Fasig, 2000). Tüm bunları yalnızca sahip olduğu nesneler için değil, aynı zamanda, diğer insanların sahip olduğu nesneler için de yapması gerekebilir. Bu nedenle, mülkiyet sosyal bilişsel bir beceri olarak ele alınabilir. Burada sıralanan bilişsel işlemlere mülkiyet gelişimi bölümünde detaylı olarak değinilecektir.

Basitçe, 'bir nesneye sahip olma' anlamına gelen mülkiyet, derinlemesine incelendiğinde, oldukça karmaşık bir yapıya sahiptir. Mülkiyet kavramı psikolojide ilk olarak tüketici davranışlarını incelemek amacıyla ele alınmıştır (Belk, 1988). Ancak o dönemde bir nesneye sahip olma durumunun bir bilgi olarak nasıl işlendiği yeterince sorgulanmamıştır. Sahip olunan şeylerin benliğin önemli birer parçası olduğunu savunan Belk (1988), bireylerin tüketim alışkanlıkları ile benlik anlayışı arasında bir ilişki olduğunu öne sürmüştür. Bir nesne ile bir insanı birbiriyle ilişkili hale getiren bu soyut bağ, çok küçük yaştaki çocukların bile görebildiği bir durumdur. Erken çocukluk döneminde henüz somut nesneler dünyasında işlem yapabildiğini varsaydığımız çocuk (Piaget, 1945/1995), nesnelerle insanlar arasındaki bu görünmeyen bağlar hakkında düşünebilir ve çıkarım yapabilir (Friedman, Neary, Defeyter ve Malcolm, 2011). Bu nedenle mülkiyetin bir kavram olarak çocuklarda nasıl geliştiğinin incelenmesi bu psikolojik yapıyı daha iyi anlamamızı da olanaklı kılacaktır.

Erken çocuklukta mülkiyet kavramının gelişimine ilişkin alan yazında sınırlı sayıda araştırma olduğu gözlenirken, Türkiye'de bu alanda yapılmış bir çalışma ise bilindiği kadarıyla henüz bulunmamaktadır. Bu derleme, mülkiyet kavramının bir psikolojik yapı 
olarak nasıl ele alınabileceğine dair bilgiler sunmayı ve var olan çalışmalarda ortaya konan gelişim süreçlerini incelemeyi hedeflemektedir. Bunun için mülkiyet üç alt başlık altında anlatılacaktır. Bunlardan ilki mülkiyet kavramının gelişimsel olarak nasıl bir yol izlediğidir. Benlik gelişimi, zihinsel temsiller ve sosyal normların kavranması gelişim sürecinin anlaşılmasında takip edilecek basamaklar olacaktır. Kavrama dair kendine içkin özellikler ikinci eksende mülkiyetin farklı boyutları olarak ele alınacaktır. Bu boyutlar, hangi nesnelerin sahiplenildiği, mülkiyet sahibinin tespiti için gereken ipuçlar1nın anlaşılması, mülkiyet hakları ve mülkiyetin aktarımını içermektedir. Mülkiyetin boyutları olarak isimlendirilen bu kavramlar, onun gelişiminin altında yatan bilişsel süreçlerin de daha iyi anlaşılmasını sağlayacaktır. Üçüncü eksende ise mülkiyetin dil ve kültür ile ilişkisi ele alınacaktır. Doğası gereği sosyal bir yapı olan mülkiyetin farklı kültür ve dil özelliklerinden nasıl etkilendiği tartış1lacaktır. Mülkiyet kavramına dair birbiri ile çelişen bulguların anlaşılabilmesi için ise ölçümün nasıl yapıldığı önemlidir. Bu nedenle mülkiyet kavramının ölçümüne dair bilgi verilecek, ölçüm yöntemlerinin farklılaşması ve bu durumun olası etkileri araştırma bulguları ile tartışılacaktır.

\section{Mülkiyet Gelişimi}

Bir nesnenin başka bir kişiye ait olduğunu bilmek, mülkiyet kavrayışının ilk adımı sayılabilir. Çocuk bunu , 'benim’ ve ‘benim olmayan' arasındaki farkı anlayarak gerçekleştirir. İki yaşındaki çocuk, belirli bir nesnenin kime ait olduğuna karar verebilir; annesinin şapkasını veya babasının ayakkabılarını tanıyabilir (Hay, 2006; Ross, 2013; Ross, Friedman ve Field, 2015; Rossano, Rakoczy ve Tomasello, 2011). Çocuğun sahip olduğu nesneye yapılan bir müdahaleye verdiği tepki de mülkiyet kavramının gelişimine ilişkin ipuçları taşır. Yaşamlarının birinci yılının sonlarına doğru bebekler, kendilerine ait oyuncakları akranları ya da kardeşleri alıp oynadığında tepki göstermeye başlar. İkinci yılın sonunda çocuklar oyuncaklarla oynama konusunda akranları ve kardeşleriyle sıkça mücadeleye girer (Brownell, Iesue, Nichols ve Svetlova, 2013). İki yaşından itibaren ise, çocuk 'benim' ve 'senin' gibi iyelik kelimelerini kullanmaya başlar (Hay, 2006). Ancak, üçüncü kişinin mülkiyetine dair anlayış, bir başka ifadeyle 'onun' şeklinde nitelendirme, dört ile beş yaşlarında gelişmeye başlar (Kanngiesser ve Hood, 2014a). Bebeklik döneminden itibaren sergilenen bazı mülkiyet davranışlarının erken ve orta çocukluk döneminde gelişmeyi sürdürdüğü düşünülmektedir (Cleroux ve Friedman, 2020; Davoodi, Nelson ve Blake, 2020; Elenbaas, 2019; Gelman, Martinez, Davidson ve Noles, 2018; Li, Shaw ve Olson, 2013). Tablo 1'de mülkiyet gelişiminde kazanılan 
kilometre taşları kısaca özetlenmiştir. Tabloda belirtilen yaşlar becerilerin gelişmeye başladığı tespit edilen ortalama/yaklaşık yaşları temsil etmektedir. Yukarıda da açıklandığı gibi, çocuk öncelikle nesneyi zihinde temsil eder, daha sonra nesne ile kişiler arasında ilişki kurar ve son olarak bu tip ilişkiler üzerine genellemeler yapmayı başarır. Fakat bunların hepsinin öncesinde, nesnenin ait olması gereken 'ben'i anlamaya ihtiyaç duyar. Bir sonraki bölümde, nesnenin ilişkilenebileceği 'ben'in oluşumu veya bebeğin kendi özerkliğini keşfetmesi olarak da tanımlanabilecek olan benliğin gelişimi ile mülkiyet arasındaki ilişkiye değinilecektir.

Tablo 1. Mülkiyetin Gelişim Süreci

\begin{tabular}{|c|c|c|}
\hline Yaş & Mülkiyet Gelişimi & Kaynaklar \\
\hline 9-12. Ay & Kendilerine ait nesneleri tanır & Brownell ve ark.., 2013 \\
\hline 14. ay & Nesnelere sahiplerinin ismi ile hitap eder & Rodgon ve Rashman, 1976 \\
\hline 18-24. ay & Nesnenin sahibini tespit eder & Fasig, 2000 \\
\hline \multirow{2}{*}{2 yaş } & "Benim" "senin" gibi iyelik zamirlerini kullanır & Hay, 2006 \\
\hline & Kendi mülkiyet hakkını savunur & Dunn ve Munn, 1987; Rossano ve ark., 2011 \\
\hline \multirow{5}{*}{3 yaş } & Mülkiyet kuralları tercihlerini etkiler & Pesowski ve Friedman, 2018 \\
\hline & Mülkiyet transferini hediye koşulunda kabul eder & Kanngiesser ve Hood, 2014 \\
\hline & Emek verilen nesnelerde mülkiyet hakkı iddia eder & Nancekivell ve ark., 2013 \\
\hline & Mülkiyet haklarını tanımaya başlar & Dunn ve Munn, 1987; Rossano ve ark., 2011 \\
\hline & “Onun” iyelik zamirlerini kullanır & Kanngiesser ve Hood, 2014b \\
\hline 4 yaş & $\begin{array}{l}\text { Mülkiyetin satın alma yolu ile kazanıldığını kabul } \\
\text { eder }\end{array}$ & Friedman ve Neary, 2008; Li, Qi, Yu ve Zhu, 2018 \\
\hline 5 yaş & $\begin{array}{c}\text { Meşru mülkiyet transferi ve meşru olmayandan } \\
\text { ayırt eder }\end{array}$ & Kanngiesser ve Hooda, 2014 \\
\hline
\end{tabular}

Mülkiyet ve Benlik Gelişimi. Sahip olunan nesnenin tanınması ve nesnenin 'ben' ile ilişkilendirilmesi, nesnelerin zihinde temsil edilebilmesini ve benlik gelişimini gerektirmektedir (Fasig, 2000). Mülkiyet kavramının gelişimi üç temel unsur üzerinden değerlendirilebilir. Bunlar sırasıyla 'benlik', 'zihinsel temsil becerisi/nesne temsili' ve 'nesne ile birey arasındaki ilişki' dir (Blake ve Harris, 2011). Buradaki zihinsel süreçler, mülkiyet kavramının zihinde canlandırılması güç ve soyut bir kavram olduğunu; sahip ve mülk arasındaki ilişkinin ise her zaman açık ve anlaşılır olmadığını göstermektedir. Benlik kavramının gelişiminde çocuğun sosyal ve bilişsel süreçleri iç içe geçmiştir. 'Benim' kavramının gelişebilmesi için öncelikle ‘ben' bilgisinin kazanılmış olması gerekir. Benlik gelişimi, bebeğin kendini dış dünyanın bir uzantısı olarak (veya dış dünyayı kendisinin bir uzantısı olarak) algılama eğiliminin ortadan kalkması ve kendinin dış dünyadan ayrışmış olduğunun farkında olmasıdır (Butterworth, 1990). Ruj testi ile 
değerlendirilen benlik kavramının yaklaşık 18-24 ay arasında geliştiği kabul edilmektedir (Pruett, 1999; Rochat, 2003). Bebeklerin bu dönemde burunlarındaki ruj lekesini aynadaki görüntülerinden değil kendi yüzlerinden silmeye çalışmaları, bebeklere kendi fotoğrafları veya video kayıtları sunulduğunda kendi isimlerini söylemeleri ve kendilerini göstermeye başlamaları, benlik gelişimine işaret etmektedir (Lewis ve Brooks-Gunn, 1979).

Benlik ve mülkiyet arasındaki ilişkinin 18-28 aylık bebeklerde incelendiği bir çalışmada, benlik kavramının daha kapsamlı bir boyutu olan benlik sürekliliği (self-continuity) bilgisi ele alınmıştır (Fasig, 2000). Bebek ve çocuklarla yapılan çalışmalarda, benlik farkındalığının çoğunlukla benliğe dair bilgiye sahip olmakla eş tutulduğunu öne süren Fasig (2000), benlik farkındalığının önemli bir boyutu olan benlik sürekliliğinin gözardı edilmesini eleştirmiştir. Benlik gelişimi incelenirken, benlik farkındalığının tüm boyutları ile ele alınması gerektiğini öneren Fasig (2000), benlik sürekliliğini de mülkiyet üzerinden 'çocuğun mülkiyeti anlaması onun benlik sürekliliğini kavramış olduğunun işareti kabul edilmelidir' şeklinde tanımlamıştır (s. 373). Çalışmada, hem bebeklerden hem de annelerden, bebeklerin benlik gelişimlerine dair veri toplanmıştır. Annelere Benlik Gelişim Ölçeği (The Self Development Questionnaire) uygulanırken, bebeklerin benlik farkındalığına sahip olup olmadıklarıalan yazında yaygın kullanılan ruj testi ile değerlendirilmiştir. Bu teste göre, burunlarına sürülen kırmızı ruj lekesini aynadaki yansımalarında gören bebeklerin, bu lekeyi kendi yüzlerinden silmeye çalıştıkları durumda benlik farkındalığını kazandıklarını kabul edilir. Eğer bebek ruj lekesine aynada gördügü yansımada dokunmaya çalışırsa henüz benliğinin fiziksel uzamda farkında olmadığ1 çıkarsanır. Benlik sürekliliği ile eş tutulan mülkiyet anlayışı değerlendirilirken ise bebeğin, annenin ve araştırma asistanının eşyaları kullanılmıştır. Bunun için aileden bebeği araştırmaya katılımcı olmaya getirirken evden bebeğe ve anneye ait bazı eşyalar (örn. diş firçası, oyuncak araba) getirmesi istenmiştir. Bu eşyaların boyutları, yeniliği, bebeğin eşyayla olan deneyimi, tanıdıklığı ve ön-yargıları kontrol edilmişsir. Bu çalışma, bebeklerin daha önce aşina oldukları nesneler aracılığıyla test edilmesi bakımından alan yazındaki diğer çalışmalardan farklılaşmaktadır. Çalışma sonucunda daha küçük yaştaki bebeklerin (18-23 ay) mülkiyeti tanıma konusunda yaklaşı \%32 oranında başarılı olduğu, daha büyük yaştaki bebeklerin (24-28 ay) ise yaklaşı \%75 oranında başarılı olduğu görülmüştür. Benlik kavramı gelişen ve gelişmeyen bebeklerin mülkiyeti tanıma konusunda birbirlerinden istatistiksel olarak anlamlı bir şekilde farklılaşmadığı tespit edil- 
miştir. Elde edilen sonuçlar, salt benlik kavramı gelişiminin mülkiyet anlayışını açıklamak konusundaki sınırlılığını gösterirken, genişletilmiş benlik bilgisinin önemine de işaret etmektedir.

Benliği salt 'ben' olarak değil; 'ben'in bilgisi olarak ele alan Neisser (1988) 'benliğe dair sahip olduğumuz bilgiyi' beş kategoride incelemiş ve 'genişletilmiş benlik' (extended self ) kavramından bahsetmiştir. Genişletilmiş benlik bilgisi, anılardan gelen bilgiyi kullanmaya ve o anda yaşananları değerlendirmeye yarayan bir düzlem yaratarak; çocuğun mülkiyet anlayışı kazanmasını sağlayan temel faktörlerden biri olarak kabul edilir (Lagattuta, Wellman ve Flavell 1997). Genişletilmiş benliğin sosyal yapılaşma yoluyla geliştiğini öne süren teorisyenler (örn., Neisser, 1988), erken dönemlerden itibaren, benlik bilgisinin diğerlerine ilişkin bilgiler ile iç içe geçtiğini iddia etmektedir (Meltzoff ve Moore, 1995). Genişletilmiş benlik hipotezi, bireyin sahip olduğu maddi şeylerin, benlik algısı ile bütünleşerek, kimliğini oluşturan yapıların bir parçası haline geldiğini savunur (Dittmar, 1992; James, 1890). Bir başka ifadeyle, kişi kendini sahip olduğu nesneler aracılığı ile tanımlamaya başlar. Fasig (2000), genişletilmiş benlik kavramını Neisser'e dayandırarak mülkiyetle ilişkilendirmiştir. Ancak tarihsel olarak çok daha erken bir zamanda James (1890), genişletilmiş benlik kavramından ve sahip olduklarımızın bu kavramın oluşumuna etkisinden bahsetmiştir. Genişletilmiş benlik hipotezinin temel iddiası, nesneleri benliğin bir uzantısı olarak gördüğümüzdür (Belk, 2000; Csikszentmihalyi ve Rochberg-Halton, 1981; Morewedge ve Giblin, 2015; Sartre, 1956/2021; Winnicott, 1953). Benlik kavramında, kimliği temsil eden hem maddi (örn., maddi değeri olan mallar) hem de manevi (örn., hobiler ve çıkarlar) mülkiyet öğelerinin bulunduğu varsayılır (Belk, 1988; Dittmar, 1992; James, 1890). Diesendruck ve Perez (2015), çocukların sahip olduğu nesneleri beş yaşından itibaren kendilerinin bir uzantısı olarak ele almaya başladıklarını ortaya koymuştur.

Belk (1988), mülkiyet ve genişletilmiş benlik ilişkisini ele almış; sahip olunan şeylerin, benliği oluşturmaya katkı sağladığını ve onu yansıttığını iddia etmiştir. Mülkiyetin insan gelişiminde işlevsel bir rolü olduğunu ifade eden Belk(1988), bu işlevleri dört aşamada açıklamıştır. Bu aşamaların ilk basamağını, bebeğin kendini fiziksel çevreden ayırt etmesi oluşturur. İkinci aşamada bebek kendini sosyal çevreden ayırt eder. Üçüncü aşamada, mülkiyetin ergenlerin ve yetişkinlerin benliklerini oluşturmalarına ve düzenlemelerine yardımcı olması açıklanır. Son olarak da yaşlılar için mülkiyet süreklilik duygusu kazanmaya yardımcıdır ve bu bir geçmiş duygusu da yaratabilmektedir. Psikolojik 
düzeydeki bu sahiplikte, benlik ve nesne arasında otobiyografik bir bağ oluşur (Redfoot ve Back, 1988). Çocuklar, kendilerini bir nesnenin sahibi olarak tanımlayabilmek için, o nesneyi geçmişte kendileriyle ilişkilendirmiş olmaya ihtiyaç duyar. Bu nedenle, benliğin sürekli veya genişletilmiş olduğu bilgisini kazanmak için çocuk, «mevcut benlikleri〉 ile ilişkilendirdikleri bir 〈geçmiş benliğin〉 ilkel temsiline sahip olmalıdır (Diesendruck ve Perez, 2015). Yapılan çalışmalar, çeşitli mülklerin biyografik referanslar sağlayarak kişinin geçmişi, bugünü ve geleceği arasında zamana bağlı bilişsel bağlantılar kurduğunu ileri sürmektedir (Redfoot ve Back, 1988). Bu iddiaya göre, kişinin kendine ait bilgiler bütünü olarak tanımlanan otobiyografik bellek (Welch-Ross, 2001), sahip olunan nesneler aracılığıyla, genişletilmiş benlik sayesinde oluşturulur. Mülkiyetle olan bu zihinsel bağlantı, sahip olunan mülklerin neden sahip olunmayan benzer eşyalardan daha akılda kalıcı, arzu edilir ve daha değerli olduğunu açıklar (Cunningham, Vergunst, Macrae ve Turk, 2013; Gelman, Frazier, Noles, Manczak ve Stilwell, 2015; Gelman, Manczak ve Noles, 2012). Çocuğun mülkiyet anlayışının, nesneleri kapsayacak biçimde genişlemiş bir benlik kavramı edinmesi sayesinde geliştiği düşünülmektedir (Rochat, 2010).

Benlik kavramı, dışarıdaki dünyayı zihninde temsil etmeyi gerektirir ve karmaşık bilişsel süreçlerin bir ürünüdür. Üst-düzey bilişsel süreçlerin üzerine inşa edildiği yapılar, zihinsel temsillerdir (Kozma, Russell, Jones, Marx, ve Davis, 1996; Piaget, 1945/1995). Günümüz alan yazınında üst-düzey düşünme becerileri yaygın olarak yürütücü işlevler (Diamond, 2013) ve zihin kuramı (Carpendale ve Lewis, 2004) gibi beceriler ile ele alınmaktadır. Zihinsel temsiller başlı̆̆ı altında öncelikle kısaca bu kavramlardan bahsedilecektir.

Mülkiyet ve Zihinsel Temsiller. Mülkiyete dair çıkarımların yapıldığg herhangi bir durumda, çocuğun dil, yürütücü işlev ve zihin kuramının ortak düzlemi dışında işlem yapması mümkün değildir. Derlemenin bundan sonraki bölümünde, bilişsel beceriler denildiğinde kastedilenin, zihinsel temsil becerisi ile yakından ilişkili olan yürütücü işlev ve zihin kuramı becerileri olduğu söylenebilir. Yürütücü işlevler çalışma belleği, bilişsel esneklik ve ketleyici kontrol gibi özgül becerilerin birbiri ile ilişkilerini kapsayan şemsiye bir kavramdır (Miyake ve ark., 2000). Ayrıca, bu sayede hedefe yönelik biçimde, duygu, düşünce ve davranışları kontrol etmeyi, problem çözmeyi ve karar vermeyi sağlar (Anderson, 2002; Carlson, 2005; Friedman ve Miyake, 2004; Miyake ve ark., 2000; Miyake ve Friedman 2012; Zelazo ve Müller, 2002). Erken çocukluk döneminde, 
özellikle de üç ile beş yaş arasında, çocukların yürütücü işlev becerilerinin büyük bir değişim geçirdiği alan yazında defalarca tekrarlanmıştır (Carlson, 2005; Carlson ve Moses, 2001; Zelazo ve Müller, 2002). Edinilen bilginin zihinde belirli bir süre ile temsil edilebilmesi ve güncellenmesinden sorumlu olan beceri çalışma belleğ $i$; göreve uygun olan temsiller (bilgiler) arasında geçiş yapabilmeyi sağlayan beceri bilişsel esneklik ve baskın/dikkat çekici uyaranları bastırıp, göreve uygun tepkinin ortaya çıkmasından sorumlu olan becerisi ise ketleyici kontrol şeklinde adlandırılmaktadır (Friedman ve Miyake, 2004; Miyake ve ark., 2000; Miyake ve Friedman 2012). Mülkiyet, nesne ve kişi arasındaki ilişkinin zihinde temsil edilebilmesini, mülkiyetin aktarıldığ 1 durumlarda yeni durumu fark etmeyi ve bilgilerin yeniden şekillendirilmesini, kişinin mülkiyet sahibini tespit ederek o nesneyle olan ilişkisini sınırlandırmasını gerektirir. $\mathrm{Bu}$ nedenle mülkiyet anlayışının gelişimi için yürütücü işlevlerin önemli bir yere sahip olduğu düşünülmektedir. Araştırmacılar, mülkiyet davranışını açıklamak için yürütücü işlevlerin değerlendirilmesi gerektiğini öne sürmektedir (McDermott ve Noles, 2018).

Yürütücü işlevlerle yakından ilişki olduğu defalarca bildirilmiş olan ve aynı şekilde üç ile beş yaş aralığında gelişimi gözlenen sosyal-bilişsel bir diğer kavram da zihin kuramidir (Carlson ve Moses, 2001; Jenkins ve Astington, 2000; Perner, Lang ve Kloo, 2002). Çocuğun dünyayı zihninde benmerkezci olmayan bir biçimde temsil edebilme başarısını ifade eden bu kavram sayesinde çocuk öncelikle kendi zihninde fiziksel dünyanın temsilleri olduğunu kavrar, daha sonra diğer insanların zihinlerinde kendisinden farklı temsiller olabileceğini anlamaya başlar (Astington, 2003). Diğer insanların kendisinden farklı inanç, duygu, istek veya amaçları olabileceğini kavrayan çocuğun zihin kuramı becerisini elde etmiş olduğu düşünülür ki bu becerinin çocuğun gelişen dil becerisi ile güçlü bir ilişkisi olduğu da öne sürülmüştür (Astington ve Jenkins, 1999). Bu kavramları kısaca açıklayabilmek için buraya kadar tali bir yol izlenmiştir. Şimdi tekrar zihinsel temsiller ile mülkiyet arasındaki ilişkiye geri dönülecektir.

Çocuklar, mülkiyeti anlamak için nesnelere ilişkin geçmiş deneyimlerinden faydalanır. Bu deneyimler, dış dünyadaki nesnelerin ve nesnelerle kurulan soyut ilişkilerin zihindeki temsillerini içerir (Noles ve Keil, 2011). Blake ve Harris (2011), mülkiyet gelişiminde doğuştan bazı yanlılıklar olduğunu ileri sürerken, nesnelerle kurulan bu özel ilişkilerin, diğger gelişimsel süreçlerden kaynaklandığını da vurgulamıştır. Bu durum, sosyal ve bilişsel süreçlerin iç içe geçtiği benlik inşası olabileceği gibi, benlik kavramını dahi öncüleyen zihinsel temsil becerisi olarak da karşımıza çıkabilir. Mülkiyetle 
ilişkili gelişimsel faktörlerin belirlenmesi oldukça güçtür. Blake ve Harris (2011), mülkiyeti anlamak için fiziksel ilişkilerin yeterli olmadığının, bu süreçlerin ötesindeki bilişsel ve soyut kavramların incelenmesi gerektiğinin altını çizmiştir. Örneğin bazı araştırmacılar, çocukların diğer kişilerle nesneler aracılığı ile ilişki kurduğunu (triadic relationship) ve bu şekilde bakım veren kişi ile bağlanmanın gerçekleştirildiğini (Winnicott, 1953); ancak bu bağlanma ilişkisinin nesnelerle olan ilişkileri anlamada bir rol oynamadığını ileri sürmüştür (Rochat, 2011). Bu becerinin gelişimsel öncüllerinin değerlendirilmesini güçleştiren bir faktör de bunların dil öncesi döneme denk gelmesidir. Blake ve Harris (2011), kalıcı ve somut sahiplik göstergelerine dayanmak yerine, mülkiyet ile mülk arasındaki ilişkiyi kabul etmek, izlemek ve güncellemek için mülkiyet bilgilerinin zihinsel temsiller yolu ile kodlanması gerektiğini öne sürer. Bu kodlamalar için pek çok farklı ipucu bulunabilir. Fiziksel ilişki, kişi ile nesne arasındaki sahiplik bağ için bir koşul ve en belirgin ipuçlarından biridir. Bebek, anne veya babasının sürekli olarak bir nesneyi kullandığını gördüğünde o nesne ile kişi arasında bir ilişki kurar ve nesnenin o kişiye ait olduğuna ilişkin bir anlayış geliştirir. Bebeğin hem nesnenin hem de kişinin adını öğrendikten sonra bu nesneye kişinin adıyla hitap etmesi kişi ile nesne arasındaki bu soyut ilişkiyi kurabildiğinin bir kanıtıdır (Blake ve Harris, 2011). Babasının her gün işe evrak çantası ile gittiğini gören çocuk, babasının çantasını işaret ederek baba der. Yani zihninde temsil etmeyi başardığı nesne, yine zihninde temsili bulunan bir kişi ile ilişkilendirilmiştir; bu da daha karmaşık bir zihinsel temsilin oluşturulduğunu gösterir. Nesne-kişi arasında ilişki kurabilme becerisi yaşa bağlı değişim gösterir. 14 ile 32 aylık bebekler nesnelere kişi ismi ile hitap etmekte (Rodgon ve Rashman, 1976) ve yeni yürümeye başlayan çocuklar kendilerine, ebeveynlerine ve diğerlerine ait eşyaları tanıyabilmektedir. Ancak daha erken dönemlerde bu ayrım henüz yapılamamaktadır (Brownell ve ark., 2013; Fasig, 2000). Daha erken yaşlarda bunun yapılamıyor olması, çocuğun henüz yetersiz dil ve/veya temsil becerisinden kaynaklanıyor olabilir.

Mülkiyet, Sosyal Normlar ve Paylaşma. Sosyal normlar, insanların belirli durumlarda nasıl davranması gerektiğini belirleyen olgulardır (Friedman ve Ross, 2011). Örneğin, bir cinsiyet rolü, cinsiyete bağlı davranış stili veya sosyal beğenirliğe uygun eylem sergilemek, sosyal normların içselleştirildiğinin işareti olarak kabul edilebilir. Piaget (1945/1995), sosyal normların okul çağından itibaren anlaşıldığını belirtirken, yapılan çalışmalar üç yaşından itibaren çocukların sosyal normları anlayabildiğini ortaya koymaktadır (Hardecker ve Tomasello, 2016; Rakoczy ve Schmidt, 2013). Malcolm, 
Defeyter ve Friedman'a (2014) göre çocuğun sosyal normları içselleştirmesinde en fazla öne çıkan özellikler yaş ve cinsiyet rolleri ve bunlara dair artan bilgileridir. Çocukların, yaş ve cinsiyete dair yaptıkları mülkiyet atıfları, sosyal normların içselleştirildiği anlamına gelir. Yaklaşık üç yaşından itibaren çocuklar bir nesnenin sahibine karar verirken cinsiyet ve yaşa dair kalıp yargılardan faydalanır (Malcolm ve ark., 2014). Yaşın ilerlemesi ile birlikte çocuklar, yalnızca bu kalıpları kullanmak yerine, farklı ipuçlarından da faydalanmaya başlar. Örneğin, üç yaşındaki bir çocuk, bir oyuncak bebeğin bir erkek çocuk yerine bir kız çocuğa ait olduğu veya bir bilgisayarın bir çocuk yerine bir yetişkine ait olduğu çıkarımını yapabilir. Yetişkinlerin yaş ve cinsiyet atıfları anlamlı bir farkl1lık göstermezken, çocuklar yaşa ve cinsiyete uygun bir sahiplik ilişkisi kurar (Malcolm ve ark., 2014). Buna göre, mülkiyet kavramı sosyal normlardan etkilenir ve geçmiş deneyimler bu süreçte rol oynar (Malcolm ve ark., 2014; Neary, Friedman ve Burnstein, 2009). Ancak, bu konudaki çalışmalar sınırlı sayıdadır ve kesin yargılara varmak için daha fazla çalışmaya ihtiyaç duyulmaktadır. Çocuğun cinsiyete bağlı mülkiyet atıflarında bulunmasını, sosyal normları kavradığının ve buna uygun davrandığının işareti olarak kabul etmek mümkündür. Öte yandan, bu duruma çocuğun dünyasına toplumsal cinsiyet rollerinin birer kalıp yargı olarak erken yaşlarda girdiğin bir göstergesi olarak da bakılabilir. Çocuğun sosyal dünyayı anlama ve ona uygun davranmaya başlamasında mülkiyetin rolünü anlamak için sosyal normlara ek olarak prososyal davranışın mülkiyet ile ilişkisini ele almak gerekebilir.

Prososyal bir davranış olan paylaşma, doğası gereği mülkiyetin ne olduğunun kavranmasını gerektirir ve çoğunlukla mülkiyetin aktarıldığı durumları içerir. Tisak ve Ford (1986) paylaşmayı kendi kaynaklarını bir başkasına fayda sağlamak için bırakmak olarak tanımlanmıştır. Çocuğun geçici olarak bir oyuncağını ya da kalıcı olarak yemeğini paylaşması, çocuklarda niyetli bir mülkiyet aktarımı anlayışı gelişene kadar paylaşma olarak nitelendirilemez (Brownell ve ark., 2013). Ancak mülkiyet anlayışı gelişen bir kişi, bir şeyin biriyle geçici olarak paylaşılması ile bir şeyin tamamen mülkiyetinin birine verilmesi arasındaki ayrımı yapabilmektedir. Yani, çocuklar bir şeyin geçici olarak birisine verilebileceğini fark edebilmektedir (Blake ve Harris, 2009). Bu ayrımı anladıklarında, çocuklar daha fazla paylaşma eğilimi gösterir (Brownell ve ark., 2013). Paylaşma mülkiyetin belirli bir süre boyunca aktarılması olarak görülebileceği için bu türlü bir davranış, özellikle küçük çocuklar için oldukça zordur (Brownell ve ark., 2013; Hay, 2006). Çünkü çocuğun sahibi olduğu nesne üstündeki mülkiyet haklarından vazgeçerek, 
onu başkasına devretmesini ve onun yararı için kullanmasını gerektirir. Bir ile iki yaşlarındaki çocuklarla gerçekleştirilen deneysel bir çalışmada, çocukların, yardıma muhtaç bir yetişkine evlerinden getirilen battaniyelerini veya oyuncaklarını verme olasılıklarının düşük olduğu bulunmuştur (Svetlova, Nichols ve Brownell, 2010). Çalışmada, ebevynlerden gelirken çocuklarına ait bir battaniye getirmeleri istenmiştir. Çocukların yarısı evden getirdikleri battaniye ile test edilerken, diğer çocuklara araştırmacılar tarafindan verilen battaniye ile test edilmiştir. Araştırmada, deneyci çocuğun bulunduğu odada belli bir mesafede dururken üşüdüğüne ilişkin fiziksel ve sözel ifadelerde bulunmuş, bu durumda çocuğun sahip olduğu battaniyeyi deneyciye verip vermediği incelenmiştir. Kendilerinin olmayan battaniye ile test edilen çocukların, kendi battaniyeleri ile test edilen çocuklara kıyasla, battaniyeyi deneyci ile daha fazla paylaştığı görülmüsştür. $\mathrm{Bu}$ durum, sahip olunan nesnelere daha fazla anlam atfedilmesinden kaynaklanabileceği gibi, küçük yaştaki çocukların karşısındakinin ihtiyaçlarını zihninde canlandırmalarında yaşadığı zorluklardan da kaynaklanıyor olabilir. Nitekim başka bir çalışmada, boş bir kapla çocuğun yanına gelip, elini açarak çocuktan yemeğini paylaşmasını isteyen bir yetişkine, 18 aylık bebeklerin $\% 40$ 'ının, 24 aylık bebeklerin ise $\% 60$ 'ının bu yetişkinle yemeğini paylaştığ 1 görülmüsşür. Dolayısıyla, paylaşma talebi, çocuğun dünyasına dair daha basit bir biçimde yapıldığında ve oyun arkadaşı ile yeterince iletişim kurabilmesi için olanak tanındığında çocukların paylaşma eğilimlerinin arttığı bulunmuştur (Dunfield, Kuhlmeier, O’Connell ve Kelley, 2011).

İki yaşından itibaren çocuklar, büyük kardeşleriyle nesneler hakkında çatışma yaşadığında mülkiyet ilkelerini kullanma eğilimi gösterir (Ross, 1996). Mülkiyet ilkelerinden biri, çocuğun nesnenin ilk sahibini sorgulamasıdır. Mülkiyet haklarının meşru yollarla aktarılması bir başka ilkedir ve izin alarak veya almadan oyuncağın el değiştirdiği durumlar buna örnek gösterilebilir. Hem akranlara hem yetişkinlere yönelik Mülkiyeti paylaşma davranışları 18 ay civarında ortaya çıkmaya başlar ve bu da mülkiyet anlayışı gelişimi ile paralellik gösterir (Brownell ve ark., 2013). Paylaşma davranışıyla mülkiyet anlayışının pozitif yönde ilişkili olduğu bulunmuştur (Brownell ve ark., 2013). 18 ve 24 aylık bebekler için mülkiyet paylaşımı beklentisi yüksek düzeyde olmadığında ve paylaşma zorunluluğu oyunlarını bırakmayı gerektirmediğinde; çocukların daha fazla paylaşma davranışı sergiledikleri görülmüştür. Aynı çalışmada, mülkiyet anlayışı ve paylaşma eğilimi yaşla birlikte artarken, yaş ve dil becerileri kontrol edildiğinde dahi mülkiyet anlayışı ile paylaşmanın pozitif yönde ilişkili olduğu tespit edilmiştir. 
Bu bölümde, mülkiyet bir zihinsel beceri olarak ele alınmıştır. Mülkiyet ile benlik gelişimi, nesne temsili ve kişi-nesne ilişkisi kurulması arasındaki ilişkiyi konu alan çalışmalara yer verilmiştir. Bunlara ek olarak, zihinsel gelişimle bağlantılı kabul edilebilen sosyal normların erken çocukluk döneminde içselleştirilmesinin ve paylaşma davranışı ile mülkiyet gelişimi arasındaki olası ilişkiye değinilmiştir. Diğer yandan, mülkiyetin farklı boyutları bulunmaktadır ve bu boyutların ele alınması, bu zihinsel yapının daha iyi anlaşılabilmesini sağlayacaktır. Bu sebeple, bir sonraki bölümde mülkiyet kavramının boyutlarına değinilecektir.

\section{Mülkiyet Kavramının Boyutları}

Mülkiyet çok yönlü bir kavramdır. Bu kavrama ilişkin, ne tür nesnelerin sahiplenilebileceği, mülkiyet ilişkisinin nasıl kurulduğu, aktarıldı̆̆ 1 , mülkiyet hakkından nasıl vazgeçildiği, belirli bir nesnenin sahibi olup olmadığı, eğer sahibi var ise sahibinin kim olduğu ve sahip olan kişinin hangi ayrıcalıkları olduğu hakkında çıkarımlarda bulunulabilir (Blake ve Harris, 2011; Friedman ve ark., 2011; Kalish ve Anderson, 2011; Noles ve Keil, 2011). Bu nedenle, mülkiyet gelişimini anlamak ve mülkiyetle ilişkili olabilecek diğer sosyal ve bilişsel süreçleri tanımlamak için bu boyutların incelenmesi gerekir. Çalışmanın bundan sonraki kısmında yukarıda bahsedilen boyutlar ele alınacak ve mülkiyet gelişiminin altında yatan süreçlere 1 şı tutulacaktır.

Hangi Nesneler Sahiplenilebilir? Mülkiyet anlayışının gelişimi yalnızca kişi odak11 değildir. Aynı zamanda kişinin nesne ile kurduğu ilişkinin de anlaşılması gerekir. Bu sebeple, mülkiyet ile ilişkili üzerinde durulması gereken bir diğer önemli konu, sahiplenilen ve hak iddia edilen nesnelerdir. Bu konuyu inceleyen araştırmalar, 'hangi tür nesneler insanlar tarafından sahiplenilebilir?' sorusuna yanıt aramıştır. Sahip olunan varlıklar, nesneler, fikirler, evcil hayvanlar gibi canlı varlıklar, topraklar, hatta tarihin karanlık zamanlarında diğer insanlar olmak üzere pek çok farklı biçimlerde karşımıza çıkabilir. Bu varlıkların çeşitliliği, ne tür nesnelerin sahiplenilebileceğine ilişkin yapılan çıkarımları akla getirir. Neary, Van de Vondervoort ve Friedman (2012) gelişimin erken dönemlerinde hangi nesnelerin sahiplenebileceğine ilişkin inanışların farklılaşacağını, insan yapımı nesnelerin (yapay nesneler; örneğin bir kitap), doğal olarak ortaya çıkan nesnelerden (doğal nesneler; örneğin bir ağaç) daha fazla sahiplenileceğini öne sürmüştür. Hipotezlerini test etmek için yaptıkları ilk çalışmada, üç ile altı yaş arasındaki çocuklara daha önceden aşina oldukları yapay ve doğal nesneler sunmuşlar ve çocuklara bu nesnelerin birine ait olup olamayacağını sormuşlardır. Elde edilen sonuçlara göre, üç 
yaşındaki çocuklar, yapay nesnelerin sahiplenilebileceğini, buna karşın doğal nesnelerin sahiplenilemeyeceğini düşünmektedir. Aşina olunan nesnelerin halihazırda sahiplenilmiş olduğu düşüncesinden hareketle, ikinci bir çalışmada çocuklara daha önce görmedikleri yapay ve doğal nesneler sunulmuş ve bu nesnelerin bir kısmının sahibi olduğu, bir kısmının ise sahipsiz olduğu söylenmiştir. Sonrasında çocuklara nesneler sunulmuş ve sahibi olanlar ile olmayanları ayırt etmeleri istenmiştir. Tüm yaş grubundaki çocuklar doğal nesnelerin sahiplenilmemiş olduğunu bildirmiş; ancak yapay nesnelerin mülkiyetine ilişkin yaşa bağlı farklılaşmalar olduğu görülmüştür. Dört ile beş yaşındaki çocuklar yapay nesnelerin sahiplenilmiş olup olmadığını anlamlı bir şekilde ayırt edemezken; altı yaşındaki çocuklar yapay nesnelerin sahibi olduğunu bildirmiştir. Dört yaş ve üstü çocukların tanıdık olmayan yapay nesnelerin mülkiyeti hakkında farklı çıkarımları olduğu görülmüştür. Aşsina olmadıkları nesnelerin insan yapımı olup olmadığı bilgisinin de verildiği koşulda, üç yaşındaki çocukların bile nesnelerin mülkiyetine ilişkin doğru çıkarımda bulunduğu görülmüştür. Nesnenin niteliğinin (yapay veya doğal) mülkiyet çıkarımında önemli bir faktör olduğu dikkat çekmiştir. Nesneye ilişkin bu bilginin çocuk tarafından gelişimsel olarak kazanılması da yine dört yaştan itibaren gerçekleşmektedir (Neary ve ark., 2012).

Mülkiyet Kararı. Bir şeyin veya nesnenin üzerinde mülkiyet iddia etmek için onun sahiplenilebilecek bir şey olup olmadığına karar vermek yeterli değildir. O nesnenin bir sahibi olup olmadığını da bilmek gerekir. Sahibi olan bir nesneyi sahiplenmeye çalışmak, sosyal açıdan olumsuz durumlara yol açabilir. Bu nedenle insanların birbirleriyle ilişkilerini etkileyen mülkiyet aynı zamanda sosyal olarak uygun davranışın ortaya çıkması için de gereklidir (Friedman ve ark., 2011; Friedman ve Ross, 2011). Örneğin, bir kişinin kendi bahçesindeki meyveleri yemesi kabul edilebilir. Ancak manavdan veya bir başkasının bahçesinden izinsiz şekilde meyve alması/toplaması doğru kabul edilmez. Çocuklar akran gruplarıyla ya da yetişkinlerin olduğu bir toplulukla bütünleşebilmek için mülkiyet ile ilgili sosyal kurallara uygun davranmak zorundadır. Sosyal olarak uygun davranış için mülkiyeti tanımak ve korumak gerekir. İnsanların nesneleri kullanmasına izin verip vermeme durumu da mülkiyete dairdir. Örneğin, oyuncağı kendisinden izinsiz bir şekilde alınan çocuk, bu duruma tepki gösterecek ve oyuncağ 1 alan kişinin oyuncakla oynamasını engellemeye yönelik davranışlar sergileyecektir.

Çocukların belli mülkiyet normlarını anlamaları için öncelikle belirli nesnelerin kime ait olduğunu tespit edebilmesi gerekir. Ancak, sosyal ilişkilerde çocuklar sıklıkla 
başkalarının sahip olduğu nesnelerle karşılaştığı için bu oldukça karmaşık bir süreçtir (Blake, Ganea ve Harris, 2012). Mülkiyetin nesneler üzerinde açık, görülebilir ve somut bir işareti olmadığı için çocuklar tarafından anlaşılması zordur (Gelman, 2009). Nesnenin dişsal özellikleri, o nesnenin mülkiyeti ile ilgili kesin bilgiler sağlamamakta, mülkiyeti anlamak için kullanılan fiziksel ipuçları ise (örn., nesneyi tutmak) yanıltıcı olabilmektedir. Örneğin, bir topla, topun sahibi olmayan bir çocuk da oynuyor olabilir. Bir diğer fiziksel ipucu olan nesneye yakın olmak da kesinlik içermez. Örneğin yanında durduğumuz araba her zaman bize ait olmayabilir. Sözel ipuçları daha çok kesinlik içerir. Ancak onlar da görsel ipuçları ile desteklenmediğinde yeterince güvenilir değildir. Çocukların görsel tecrübeye kıyasla sözel bilgiyi tercih etme eğilimleri pek çok farklı bilgi işleme süreci için geçerli kabul edilmektedir (Gelman, 2009; Harris ve Koenig, 2006). Fiziksel ipucu mülkiyet anlamına gelmediğinde, sözel ipuçlarının durumu netleştirdiği söylenebilir. Dört yaşından önce çocukların sözel veya fiziksel ipuçlarından herhangi birine öncelik vermediği görülmüştür. Dört yaşından büyük çocuklar ise fiziksel ipuçlarının yanıltıcılığına kapılmayarak sözel ipuçları ile mülkiyet atıflarında bulunurlar (Blake ve ark., 2012). Mülkiyetin kime ait olduğunu anlamak için görsel ipuçlarına yönelik yanlılığgn ise beş yaşından itibaren ortadan kalktığg ve çocukların kendi gözlemlerine veya sözel olarak onlara anlatılanlara dayanarak mülkiyet atıflarında bulundukları ortaya çıkmıştır (Blake ve Harris, 2009). Çocuğun, kimin neye, ne zaman sahip olduğu anlayışının altında onun zihinsel temsil becerisinin yatıyor olduğu düşünülmektedir (Blake ve Harris, 2009).

Çocukların zihninde istekler ile sosyal normların ve mülkiyet haklarının çatışması karmaşa yaratan bir durumdur (Pesowski ve Friedman, 2018). Böylesi bir çatışma durumunda mülkiyetin kime ait olduğuan karar verme konusunda çocuklar yaşa bağlı olarak farklı yanıtlar verebilmektedir. İki kişinin benzer büyüklükteki bir nesne için çatıştığı bir senaryoda, altı ile sekiz yaşındaki çocuklar çatışmayı ortadan kaldırmak için daha çok isteyen tarafın o nesnenin sahibi olması gerektiğini söylemişlerdir (Pietraszewski ve Shaw, 2015). Bu çalışmada çatışmanın ortadan kalkması için çocukların bir tarafa mülkiyeti atfetmeleri gerekmiştir ve çocuklar sahip olma isteğini mülkiyetin bir gerekçesi olarak kullanmışlardır. Öte yandan, Pietraszewski ve Shaw'dan (2015) farklı olarak, istek ve tercihler hakkında verilen kararlar üzerinde mülkiyetin etkisi de incelenmiştir. Mülkiyet, insanın tercih ve arzularına karşıt biçimde hareket etmesini gerektirdiğinde, erken çocukluk dönemindeki çocuklar bu durumu anlamakta zorlanır (Pesowski ve 
Friedman, 2018). Beş yaşından küçük çocuklar, bir kişinin arzu ve istekleri mülkiyet kurallarına ve ahlaki ilkelere aykırı olduğunda kişinin arzu ve isteklerine göre hareket edeceğini, insanların arzu ve isteklerinin aksi yönünde hareket edemeyeceğini belirtmektedir (Pesowski ve Friedman, 2018). Üç ile altı yaşındaki çocuklarla yapılan bu çalışmada, beş yaşından küçük çocukların bir nesnenin sahibine karar verirken, mülkiyete ilişkin ipuçları olmasına rağmen, bir nesnenin sahibinin onu en çok isteyen kişi olduğunu düşünebildikleri belirtilmiştir. Beş yaşından büyük çocuklar için ise mülkiyet bilgisi, bir nesnenin kime ait olduğunun bulunmasında istek ve tercihlerin üstündedir. Pesowski ve Friedman (2018) ise mülkiyet kavramının davranışlar hakkında verilen kararlar üzerinde etkili olduğunu, ancak tercihler hakkında karar verirken etkili olmadığını ileri sürmüştür. Üç ile altı yaş arasındaki çocuklarda, mülkiyetin eylemler ve tercihler üzerindeki etkisi kahramanın isteklerinin mülkiyet ayrıcalıkları ile çatıştığı bir senaryo aracıllğıyla incelenmiş̧ir. Çocukların anlayabilmesi için oldukça kolaylaştırılmış ve resimlerle desteklenmiş olan bu senaryoda, kırmızı elmayı seven ve karnı aç olan bir çocuk yürürken kırmızı ve yeşil elma ağaçları görür. Kırmızı elma ağacının sahibinin senaryodaki çocuk veya karşı cinsiyetten bir yetişkin olduğu iki koşul oluşturulmuştur. Çocuğun tercih etmediği yeşil elma ağacının ise her iki koşulda da sahibi yoktur. Bu senaryodaki kahramanın hangi ağaçtan elma almayı seçeceği ve bunun doğru olup olmadığ 1 çocuklara sorulmuştur. Ağacın sahibinin senaryodaki çocuğun kendisi olduğu koşulda, tüm çocuklar aç olan çocuğun tercihi ile uyumlu olan kırmızı elmayı seçeceğini belirtmiştir. Ağacın sahibinin bir başkası olduğu koşulda ise, yaşça büyük çocuklar, küçük çocuklara kıyasla, aç olan çocuğun anlamlı şekilde daha fazla oranda yeşil elmay1 seçeceğini söylemiştir. Aynı çalışmada, senaryodaki çocuğun cinsiyetini dengelemek amacıyla, büyük deniz kabuğunu almayı tercih eden bir kız çocuğunun yer aldığı senaryo aynı prosedür ile sunulmuştur. Bu iki senaryoda da yukarıdaki bulgular geçerli olsa da, çocukların sahip olmak istedikleri nesneler insan yapımı değil, doğal nesnelerdir. Bunun karıştırıcı etkisini de ortadan kaldırmak ve tercihlerle eylemler arasındaki farkı incelemek için ikinci bir çalışma daha yapılmıştır. Pesowski ve Friedman'ın (2018) raporladığı iikinci çalışmadaki senaryoda, bir kız çocuğu iki yanında birer oyuncak vagon ile resmedilmiş, çekici bir görünüşü olmayan oyuncak vagonun bu kız çocuğuna, çekici (güzel) oyuncağın ise bir başkasına ait olduğu belirtilmiştir. Eylem koşulunda çocuklara, senaryodaki aktörün (çocuğun) hangi oyuncağı alıp eve götüreceği, tercih koşulunda ise hangi oyuncağ 1 eve götürmek isteyeceği sorulmuştur. Kontrol amacıyla ise oyuncakların kime ait olduğu söylenmeden, çocuğun hangi oyuncak ile eve gitmek isteyeceği 
sorulmuştur. Eylem koşulunda çocuklar senaryodaki çocuğun kendine ait olduğu söylenen oyuncak ile eve gideceğini söylemişlerdir. Tercih koşulunda, senaryodaki çocuğun daha güzel olan oyuncak ile eve gitmek isteyeceği bildirilmiştir. Araştırmacılar bu çalışmadan elde ettikleri sonuçları, çocukların mülkiyete dayanarak eylemleri tahmin ettikleri, fakat tercihleri tahmin ederken mülkiyet bilgisini dikkate almadıkları şeklinde belirtmiştir.

Mülkiyet Hakları ve Aktarımı. Mülkiyete ilişkin bir diğer önemli konu da mülkiyetin getirdiği birtakım ayrıcalık ve haklardır. Bir kişinin nesnenin kullanımına ilişkin söz sahibi olmasının, aynı zamanda onun nesnenin sahibi olduğuna dair bir ipucu olduğu daha önceki bölümlerde belirtilmişti (Neary, Friedman ve Burnstein, 2009). Örneğin, bir eşyanın mülkiyetine sahip olan kişi, o eşyayı başkasının kullanmasına izin verme veya vermeme hakkına (veya ayrıcalığına) sahiptir. Üç yaşından büyük çocuklar, diğerlerinin nesneyi kullanıp kullanmayacağı hakkında kararı veren kişiyi nesnenin sahibi olarak tanımlamaya başlar (Nancekivell, Van de Vondervoort ve Friedman, 2013).

Mülkiyet haklarının bilinmediği durumda, kendine ait olan bir nesnenin başkası tarafından kullanılması, nesnenin artık başkasının olduğunun düşünülmesine ve mülkiyetin yitirilmesine neden olabilir (Nancekivell ve ark., 2013). Araştırmalar iki yaşındaki çocukların dahi mülkiyet haklarını savunduğunu, üç yaşındaki çocukların ise mülkiyet haklarının normatif boyutlarını anlamaya başladığını göstermektedir (örn., 'O benim!'; Dunn ve Munn, 1987; Rossano ve ark., 2011). Bununla birlikte, küçük çocuklar yetişkinlere ve daha büyük çocuklara kıyasla, mülkiyet haklarına ilişkin daha az eylemde bulunabilir. Örneğin, dört ile beş yaş arasındaki çocuklar, mülkiyet sahiplerinin davranışlarına ilişkin değerlendirme sürecinde mal sahiplerinin mülklerini değiştirmesi veya yeni yollarla kullanması gerektiğini reddederken, daha büyük çocuklar ve yetişkinler mal sahiplerine mülklerinin daha geniş kontrolünü verir (Kim ve Kalish, 2009). Bunun nedenleri arasında, daha küçük yaştaki çocukların benmerkezciliğii, çeşitli bilişsel sınırlılıklara sahip olmaları ve henüz soyut düşünme becerisine sahip olmamaları olabilir. Ayrıca mülkiyetin devredilmesine ilişkin bilgilerin bu dönemde henüz yeterli olmaması veya isteklerin mülkiyet haklarının önüne geçmesi de nedenler arasında sayılabilir. Mülkiyet, çeşitli haklar sağladığı kadar, nesnelere ilişkin duygu ve davranışlar üzerinde de belirleyici ve düzenleyici bir etkiye sahip olabilir; ki bu sahip olmak için seçilen nesne tercihlerinde kendini gösterebilir. 
Mülkiyet, çocukların nesneler için tercihlerini (Gelman ve ark., 2012) ve bu nesnelerin çocuklar için önemini belirler (Cunningham ve ark., 2013). Çalışmalar, mülkiyetin çocukların tercihlerini etkilediğini göstermektedir. Çocukların yakın zamanda kendilerine verilen nesneleri tercih etme eğilimleri, diğer nesnelere kıyasla yüksektir (Pesowski ve Friedman, 2018). Yapılan bir çalışmada, çocuklara üç özdeş nesne sunulmuştur. Bu nesneler sahiplik bilgisiyle etiketlenmiş (örn., 'Bu benim; bu senin; buna bak') ve karıştırılmıştır. Daha sonra çocuklardan en sevdikleri nesneyi seçmelerini istenmiştir. Çalışma çocuklara özdeş olmayan özelliklere sahip üç farklı nesne sunularak aynı prosedür tekrar edilmiştir. İki, üç ve dört yaşlarındaki çocuklar en çok sevdikleri nesne olarak kendilerine ait olan nesneyi seçmiştir (Gelman ve ark., 2012). Sonuçlar, mülkiyetin bir nesnenin algısal veya işlevsel özellikleri açısından yorumlanmadığını, çocukların kendilerine atanan oyuncağı tutarlı bir şekilde seçme eğiliminde olduğunu ortaya koymaktadır. Üç yaşındaki çocuklarla gerçekleştirilen başka bir çalışmada da çocukların kendi nesnelerini yeni getirilen nesneye tercih ettiği görülmüştür (Gelman ve Davidson, 2016). Bu durum, insanların sahip oldukları şeylere daha fazla değer atfetme eğilimlerine işaret etmektedir (Reb ve Connolly, 2007).

Araştırmacılar bu durumu, kişinin bir nesneye sahip olduğunda (yani kişiye bir sahiplik atandığında) sahip olduğu nesneyi sahip olmadığı duruma kıyasla daha değerliymiş gibi düşünme yanlılığı olan 'değeri kendinden menkul olma etkisi' (endowment effect) olarak açıklamaktadır (Thaler, 1980). Benlik ve mülk arasında gelişen bu ilişki yanlılığının özellikle Batı toplumlarında daha güçlü olduğu belirtilmektedir (Hood, Weltzien, Marsh ve Kanngiesser, 2016). Hatta çocukların bir nesnenin değerini belirlerken, bu nesneye sahip olma tarihçesini hesaba katabildiği ve kendi sahip oldukları nesnelere daha yüksek değer biçtiği ve bir nesnenin duygusal ve ekonomik değerini de bu tarihçeye göre belirlediği ifade edilmiştir (Hood ve Bloom, 2008). Hood ve Bloom (2008), erken çocukluk döneminde tipik gelişim gösteren çocukların, Kraliçe Elizabeth'e ait bir nesne ile o nesnenin replikasının aynı değere ait olmadığını anladıklarını ifade etmiştir. Yani çocuklar birebir aynı görünse de, maddi değeri düşük olan bir nesneye bile; ona sahip olan kişilerin tarihçesine bağlı olarak daha fazla değer atfedebilmekte, sahiplik tarihçesini hesaba katmaktadırlar. Birebir aynı iki kaşıktan birisi Kraliçe Elizabeth'e ait ise; bu kaşık, onunla tüm özellikleri aynı olan diğer kaşıktan daha değerli kabul edilebilir. Bu her zaman, bu örnekteki gibi, önemli kişilere ait nesnelerin daha değerli kabul edilmesi olarak anlaşılmamalıdır. Çocuklar için nesneye sahip olan kişi 
kendisi olduğunda da o nesnenin değeri artmaktadır (Hood ve Bloom, 2008). Örneğin arkadaşım ve ben birebir aynı oyuncak ayıcığa sahip olabiliriz ancak benim için bana ait olan ayıcık daha değerlidir. Farklı gelişim özelliklerine sahip çocukların sahip tarihçesini nasıl kullandıkları incelendiğinde bir nesnenin değerini biçerken, otizm spektrumundaki çocukların kendi sahip oldukları nesneye daha fazla değer biçme eğiliminde olmadıkları görülmüştür (Hartley ve Fisher, 2018). Hartley, Fisher ve Flecther (2020a) otizm spektrumundaki çocukların, nesnenin mülkiyet tarihçesini dikkate almadığını ileri sürmüştür. Otizm spektrumundaki bireylerde, benlik kavramı gelişimi farklı bir süreç izlediği için bu durumun ortaya çıktığı düşünülmüştür (Hartley ve Fischer, 2018).

Çocukların mülkiyete sahip olmanın getirdiği avantajların farkında olduğu kabul edilmekle birlikte bir diğer önemli konu, mülkiyete sahip kişinin bir başkası olduğu durumda çocuğun eylemlerinin değişip değişmeyeceğidir. Kendisine ait olan şeylerin mülkiyet anlayışı ile diğerlerine ait olanların mülkiyet anlayışının incelendiği bir çalışmada, iki yaşındaki çocukların sahip oldukları eşyaları başkaları almak istediğinde tepki gösterdiği; öte yandan başkalarının sahip olduğu nesnelere kendileri saygı gösterse de üçüncü bir kişi o nesneleri almak istediğinde tepki göstermediği gözlenmiştir (Kanngiesser ve Hood, 2014b). Bu bulgu, iki yaşındaki çocukların kendi mülkiyet haklarının farkında olduğunu, ancak diğerlerinin haklarını bilmedikleri veya kendi haklarını savunmayı bildikleri halde, başkalarının haklarını savunmayı bilmedikleri şeklinde yorumlanabilir (Nancekivell ve ark., 2013). Benzer şekilde, üç ile dört yaşındaki çocuklara, bir yetişkin tarafından oyuncağın çocuğun kendisine ait olduğu söylediğinde, çocuğun o oyuncağ1 daha fazla savunma eğiliminde olduğu görülmüştür (Blake ve ark., 2012). Bu bağlamda, sosyal ortamda diğer kişilerden alınan bilgilerin mülkiyet için önemli bir ipucu sağladığı düşünülebilir.

Yukarıda da belirtildiği gibi, mülkiyete ilişkin karar verirken çocuklar birçok farklı ipucundan faydalanmaktadır. Bir nesnenin sahibinin kim olduğunu tespit etmek ve sahiplik hakları kadar, bu hakkın nasıl kazanıldığı ve aktarıldığı da anlaşılmalıdır. Çünkü çoğunlukla mülkiyet bir kişiden diğerine devredilerek edinilir. Bu nedenle, mülkiyet gelişimini anlamak için mülkiyetin kişiden kişiye aktarımını, mülkiyeti devretmenin meşru ve meşru olmayan yöntemlerini çocuğun nasıl anladığını bilmek gereklidir. Örneğin, bir kişi araba satın aldığında, arabanın mülkiyetini alır, ancak bu kişi arabayı çaldıysa arabanın mülkiyetini yasal olarak almış olmaz. Mülkiyet kavramının erken dönemlerde geliştiği bilinirken, mülkiyetin devredilmesine ilişkin anlayış önceki süreçlerden farklı 
olarak gelişmektedir (Nancekivell ve ark., 2013). Mülkiyetin kalıcı olarak devredilebileceği ve meşru olan aktarım (hediye etme) ile meşru olmayan aktarımı (çalma) birbirinden ayırt etme becerisi farklı bir gelişimsel süreç takip etmektedir (Friedman ve Neary, 2008; Kanngiesser ve Hood, 2014a; Li, Qi, Yu ve Zhu, 2018). Mülkiyet aktar1mındaki gelişimsel farklılıklar incelendiğinde, yaşa dair birtakım çelişkili bulgular olduğu görülmektedir. Kanngiesser ve Hood'un (2014a) çalışmasında beş yaşındaki çocuklar mülkiyet aktarımının hediye yoluyla gerçekleşebileceğini kabul ederken, çalma durumunda mülkiyet aktarımını kabul etmemişlerdir. Dört yaşındaki çocukların ise meşru olan aktarımı, meşru olmayandan ayırt etmekte zorlandığ 1 görülmüştür. Ancak, yine de hediye durumunda (meşru koşulda) mülkiyet aktarımına izin verdikleri gözlemlenmiştir. Buna karşın, Blake ve Harris'in (2009) çalışmasında dört ve beş yaş çocuklarının meşru ve meşru olmayan aktarımları birbirinden ayırt edebildiği bulunmuştur. Meşru ve meşru olmayan transferlerin incelendiği çalışmalardan elde edilen farklılaşmanın ölçüm yöntemlerinden kaynaklanabileceği düşünülmektedir. Çünkü Kanngiesser ve Hood (2014a) çocukları senaryolar ile test ederken, Blake ve Harris (2009) çocukları kuklalar ile test etmiştir. Çocukları değerlendirmeden önce hikayeye ait kontrol soruları bulunmakla birlikte (örn. bellek kontrolü yapabilmek için 'hikayenin başında oyuncak kime aitti?' sorusu), bu desen çocukların bellek ve dikkat becerileri ile de yakından ilişkilidir. Çünkü çocuklar hikayeyi akıllarında tutmalı, aynı zamanda sunulan bilgileri işlemden geçirebilmelidir. $\mathrm{Bu}$ beceriler göz önünde bulundurulduğunda, kuklalar ile ölçüm almanın bilişsel yükü senaryolarla test etmeye kıyasla daha düşük olduğu düşünülmektedir. Bu nedenle çocuklar daha erken yaştan itibaren bu görevleri başarabilmektedir.

Erken dönemlerde mülkiyet aktarımı yeterince yapılmazken, beş yaş civarında bu temsil düzeyinin geliştiği düşünülmektedir. Çocuklar henüz üç yaşındayken bile hediye alışverişi olduğunda mülkiyetin aktarıldığını anlarken, dört ya da beş yaşına geldiklerinde mülkiyetin ancak satın alma yoluyla kazanıldığını anlamaktadır (Friedman ve Neary, 2008; Li ve ark., 2018). Ayrıca üç ile dört yaşındaki çocuklar, bir kişinin bir nesne üzerinde emek sarf etmesi durumunda (örn., oyun hamurundan ördek yapmak), o kişinin ortaya çıkan nesnenin mülkiyet hakkına sahip olacağını kabul etmektedir (Nancekivell ve ark., 2013). Somut şeylere ilişkin mülkiyet hakkı daha kolay tespit edilirken, fikir gibi soyut şeylere ilişkin mülkiyetin tespit edilmesi çok daha zordur. Çocukların fikirlerin mülkiyetini anlayıp anlamadığını değerlendirmek için intihal (benzerini oluşturma) 
ve kopyalama (birebir, olduğu gibi alma) durumlarına verdikleri tepkiler incelenebilir. Çünkü intihali olumsuz olarak değerlendirebilmek için başkalarının kendilerine ait fikirleri olduğunu ve bunları sahiplenmenin yanlış olduğunu kabul etmek gerekir (Olson ve Shaw, 2011). Çocukların intihale ilişkin kaygılarının kaç yaşından itibaren ortaya çıktığını araştırmak için üç ile altı yaş arasındaki çocuklara intihal durumunun yaşandığı bir video sunulmuştur (Olson ve Shaw, 2011). Videoda iki kukla birlikte resim çizerken, bir kukla diğerinin resmine bakar ve daha sonra aynı, benzer veya farklı bir şey çizmeye devam eder. Aynı resim koşulunda tam bir kopyalama durumu, benzer çizim koşulunda ise çocukların intihale ilişkin tutumları incelenmiştir. Sonrasında çocuklardan ikinci kuklanın davranışını değerlendirmeleri istenmiştir. Sonuçlara göre, beş yaşından itibaren çocukların başkalarının sanat eserlerini kopyalayan veya intihal eden kişilerin davranışlarını olumsuz olarak değerlendirdiği, ancak daha küçük yaştaki (3-4 yaş) çocukların henüz bu ayrımı yapamadığı tespit edilmiştir. Bununla birlikte, büyük çocukların kopyalama durumunu, intihal durumuna kıyasla çok daha olumsuz olarak değerlendirildiği görülmüştür.

Fikir mülkiyeti üzerinde kültürün etkisini incelemek için, üç ülkede (ABD, Meksika ve Çin) yukarıdakine benzer bir senaryo kullanılarak bir araştırma gerçekleştirilmiştir (Yang, Shaw, Garduno ve Olson, 2014). Bu üç kültürde de beş ve altı yaşlarındaki çocuklar intihal yapan kişileri, tamamen farklı bir çizim yapan kişilerle kıyaslayarak 'olumsuz davranış sergiliyor' olarak değerlendirmiştir. Bu sonuçlar, intihale ilişkin olumsuz tutumların beş yaşından itibaren gözlemlenebildiğini ve fikrin korunmasına ilişkin farklı değerlere sahip oldukları düşünülen kültürlerden gelen çocukların evrensel bir gelişim eğrisine sahip olduğunu göstermiştir. Bu konudaki diğer tartışmalara mülkiyet ve dil-kültür ilişkisi başlı̆̆ı altında tekrar değinilecektir.

\section{Mülkiyette Dil ve Kültür Etkisi}

Mülkiyet anlayışı sosyal süreçleri etkilediği gibi, sosyal süreçler de mülkiyet anlay1Şını etkilemektedir. Sosyal süreçler, mülkiyet anlayışının, aktarımının ve avantajlarının anlaşılmasında rol oynayan bir etmendir ve kültür ile iç içe, doğrudan kültürden etkilenen özelliktedir (Malcolm, Defeyter ve Friedman, 2013; Nancekivell, Van de Vondervoort ve Friedman, 2013; Yang ve ark., 2014). Bu nedenle, insanların sahip olduğu nesnelere yönelik düşüncelerini ve davranışlarını önemli ölçüde etkileyen, insan toplumlarının yapısına derinlemesine işlemiş bir sosyal kurum olan mülkiyet kavramının, içinde yaşanılan kültürden etkilendiğini düşünmek mümkündür. 
Dil, kültürün en önemli bileşenidir. Gelişim alanındaki tüm çalışmalar gibi mülkiyet kavramı da dil ve kültür bağlamından ayrı düşünülemez. İlk olarak, dil becerileri ele alındığında, iyelik zamiri kullanımının çocuklarda mülkiyet anlayışını geliştirdiği ve bunun da sosyal süreçlerde çocuklara kolaylık sağladığı düşünülmektedir (Aikhenvald, 2013; Dixon, 2015; Friedman ve Neary, 2008; Hay, 2006; Shi, Zhou, Han ve Liu, 2011). Dil yapıları incelendiğinde, İngilizce gibi Germen dillerinde iyelik, bir kelime ile ifade edilmekte (mine, yours vb.) ve sahiplik bildiren ekler nesnenin başına getirilmektedir (my, her, his vb.). Türkçede ise iyelik, kelimelerle ifade edilebileceği gibi (benim, senin vb.) sözcük sonuna getirilen eklerle de anlatılabilir. Farklı iyelik kalıplarının ek veya sözcük olarak kullanımında değişiklik gösterebilmektedir (Possessive, 2021). Aitlik bildiren ifadelere daha fazla maruz kalan çocuklarda mülkiyet kavramının gelişiminin farklılaşacağı, hatta daha erken gelişebileceği sorusu akla gelebilir. Yapılan çalışmalar dil kazanımı, kelime dağarcığı ve kullanılan kelime türlerinin kültürlerarası farklılaşma gösterdiğini ortaya koymaktadır (Aksu-Koç ve ark., 2011; Choi ve Gopnik, 1995; Fenson ve ark., 2007). İngilizce yapılan çalışmalar çocukların ilk kelimelerinin isim ağırlıkl1 olduğunu bildirir; ancak Çince, Korece ve Türkçe yapılan çalışmalar bu dillerde, çocukların fiilleri de isimler kadar erken kullandığını göstermiştir (Aksu-Koç ve ark., 2011; Tardif, 1996). Farklı dillere maruz kalarak büyüyen çocukların, benzer biçimde zamir ve iyelik eki kullanımı da farklılaşabilir. Alan yazında bu konuda yapılan bir çalışma yoktur; ancak Türkçe gibi sondan eklemeli ve iyeliğin vurgulandığı bir dile maruz kalarak büyüyen çocukların mülkiyet kavramı incelenmeye değerdir.

Mülkiyet kavramı gelişimi bölümünde, ebeveyn ve çocuk ilişkisine bir nesnenin dahil olmasının (triadic relationship) önemi vurgulanmıştı. Bu üçlü ilişkinin çocukların dil gelişiminde etkili olduğu bilinmektedir (Bates, 1976). Kültürün bu üçlü ilişki süreçlerini etkilediğini gösteren çalışmalar da bulunmaktadır (Feldman ve Masalha, 2010; Hedenbro, Shapiro ve Gottman, 2006). Bu nedenle dilin hem doğrudan kullanımı hem de aracı rolü mülkiyet gelişiminde etkili olabilir. Mülkiyet anlayışının gelişimine ilişkin bilginin giderek artmasına karşın, alan yazında bu konu ile ilgili Türkiye' de yapılmış bir çalışmaya rastlanmamıştır. Ayrıca alan yazındaki birçok çalışmanın katılımıı sayısı da oldukça azdır. Türkiye'de bu konuya dair yapılacak bir çalışma, kültürel farklılıkların değerlendirilebilmesini mümkün kılacak ve mülkiyet gelişimi konusunda elde edilecek olan yeni bilgileri alan yazına kazandırmış olacaktır.

Mülkiyet anlayışındaki kültürel farklılıkları anlamak, mülkiyet anlayışının nasıl ge- 
liştiğine dair soruların daha iyi açıklanmasını sağlayacaktır. Konfüçyen inanışlara sahip olan kültürlerde büyüyen çocukların yürütücü işlev ve zihin kuramı gibi bilişsel becerilerinin, Avrupa ve Amerika'da büyüyen çocuklardan farklılaştığını gösteren çalışmalar mevcuttur (Lewis ve ark., 2009). Aynı zamanda, Lucas, Lewis, Pala, Wong ve Berridge'in (2013) çalışmasına göre, Türkiye'de yaşayan çocukların bilgiye dayalı (epistemik) seçici güven ve zihin kuramı becerilerinin, Çin ve İngiltere' de büyüyen yaşıtlarından farklı özellikler sergilediği gözlemlenmiştir. Buna göre, Türkiye'de yaşayan çocukların zihin kuramı becerilerinin, İngiliz ve Çinli çocuklardan daha erken yaşta geliştiği ve bilgi kaynağının tespitinde güven esnekliğini de yine diğer kültürlerden gelen akranlarından daha erken kazandıkları bildirilmiştir. Çalışma sonuçlarındaki kültürlerarası farklılıkların, Türkçedeki zaman zarflarının (örn., -dı, -mış vb.) cümlenin anlamını güçlendirmesinden kaynaklanabileceği belirtilmiştir. Üç-dört yaş aralığında hızla değişen pek çok bilişsel beceri arasında zihin kuramı bulunduğu gibi bu zaman aralığında mülkiyet kavramı da gelişmektedir (Nancekivel ve ark., 2013). Mülkiyet anlayışının temelinde yer alan zihinsel temsil ve bu temsillerin esnek biçimde zihinde işlenmesi, nesne-insan arasında ilişkilerin gerektirdiği ketleme veya bellek yükleri bu becerinin yürütücü işlevlerle yakından ilişkili olabildiğini düşündürmektedir. Dolayısıyla bu bilişsel temeller göz önünde bulundurulduğunda mülkiyetin gelişiminin bu bilişsel becerilerle ilişkisi kadar kültürler arasında benzer bir farklılaşmanın olup olmadığına bakmak da önem arz etmektedir.

Kanngiesser, Itakura ve Hood (2014) tarafından gerçekleştirilen mülkiyet ile ilgili kültürel ve gelişimsel farkların incelendiği bir çalışmada, araştırmacılar, üç ve dört yaŞındaki Japon ve İngiliz çocuklar ile yetişkinlerin, bir nesnenin üretiminde ona emek veren kişiye yaptığı mülkiyet atıflarını incelemiştir. Katılımcılara, iki kuklanın bir kağıt üzerinde mülkiyet iddia ettiği bir senaryo izletilmiştir. Birinci kukla eline bir kağıt almış, bunun kendi kağıdı olduğunu söyleyerek, onu ortalarında duran kutuya kaldırmıştır. Ardından ikinci kukla bu kağıdı almış ve üzerine bir resim yapmıştır. Daha sonra katılımcılara bu yeni ürünün, yani üzerinde resim bulunan kağıdın mülkiyetinin kime ait olduğu sorulmuştur (Bu yeni ürün, kağıdın ilk sahibi olan birinci kuklaya mı, yoksa üzerine resmi çizme emeğini gösteren ikinci kuklaya mı aittir?). Japon çocukların mülkiyeti emek veren kişiye atfetme eğitimleri İngiliz çocuklardan daha düşükken, Japon yetişkinlerin ise mülkiyeti emek veren kişiye atfetme eğitimleri İngilizlerden daha yüksektir. Her iki kültürden gelen yetişkinler ve yalnızca İngiliz çocuklar bu yeni ürünü 
oluşturan kişiye mülkiyet atfederken, Japon çocuklar kağıdın ilk sahibine mülkiyet atfetmiştir. Bu çalışmadaki senaryolarda mülkiyet tespiti kurallarından yalnızca ilk sahip olma ve emek verme durumları kullanmıştır. Japon ve İngiliz çocukların sosyal muhakeme becerilerinin birbirinden farklılaşıyor olması, Japon çocukların ilk sahip yanlılı̆̆ını sergilerken, İngiliz çocukların böyle bir yanlılık sergilememelerini açıklayabilir. Araştırmalar, Japon çocukların sosyal muhakeme becerilerinin beş ila altı yaş arasında ortaya çıktığını ve bunun Batılı çocuklardan yaklaşık 1.5 yıl geç olduğunu göstermektedir (örn., Naito ve Koyama, 2006). Bu nedenle İngiliz çocuklar mülkiyet bilgisini muhakeme edip emek harcayan kişiye atfedebilirken, Japon çocuklar muhakeme konusunda sıkıntı yaşamış ve sahip oldukları mülkiyet bilgisini işlemeden genellemiştir.

Mülkiyet boyutlarında açıklandığı gibi bir nesneye sahip olma koşulları, ilk sahip olma ve emek verme durumlarından çok daha çeşitli biçimlerde karşımıza çıkabilir. Örneğin, bir nesnenin meşru veya meşru olmayan el değiştirmesine çocuklar kültürel olarak farklı yaşlarda duyarlı hale gelebilir. Li ve arkadaşları (2018), yalnızca Çinli çocuklarla yaptıkları çalışmada, üç yaşındaki çocukların mülkiyet hakkının çalma gibi meşru olmayan durumlarla aktarılamayacağını bildirmiş ve bunu Çin kültüründe bir nesneyi elde etmek için emek vermek gerekliliğine çokça yapılan vurguya dayandırmıştır. Üç yaştan beş yaşa geçerken çalma, hediye etme veya terk etme gibi durumları tespit ederek mülkiyet haklarını buna uygun dağıtan bu Çinli çocukların evrensel bir doğruyu akranları ile paylaşıp paylaşmadıkları incelenmeye değerdir. Bu nedenle böylesi bir mülkiyet çalışması farklı bir kültürde tekrar edildiğinde, kültürün bu hakların aktarımına veya emek verme üzerindeki vurgusuna da dikkat etmelidir. Yukarıda da ifade edildiği gibi bu derleme kapsamında bilişsel yükleri bakımından benzerlik gösterdiği düşünülen yürütücü işlevler veya zihin kuramı Doğulu (toplulukçu) ve Batılı (bireyci) kültürlerde farklı gelişimsel örüntüler izleyebilmektedir. Mantıksal çıkarım becerisi olarak nitelendirebilecek mülkiyet kavramı da üst düzey bir bilişsel beceri olarak benzer bir etkiye maruz kalıyor olabilir. Tüm diğer bilişsel ve sosyal gelişim alanlarında olduğu gibi mülkiyet gelişimi söz konusu olduğunda da kültür ve dil ilişkisi birbirinden ayrılması güç ve birlikte incelenmesi gerekli kavramlardır. Ayrıca, çocukların mülkiyet sorularını sözel olarak yanıtlamaları nedeniyle dil becerileri ile fazlasıyla ilişkili olan bu becerinin, çocuğun maruz kaldığı dil yapısından etkilenme olasıllğ̆ olduğu düşünülebilir.

Mülkiyetin incelenmesinde yaygın olarak kullanılan araç senaryolardır ve dolayısıyla dil becerilerine fazlasıyla bağımlı ölçümlerdir. Mülkiyet çalışmalarında sıklıkla çocuklara bir senaryo sunulmakta, sonrasında çocukların cevaplarını sözlü olarak veya 
parmakları ile ifade etmeleri beklenmektedir. Örneğin, Li ve arkadaşlarının (2018) yaptığı çalışmada çocuklara nesnenin sahibinin kim olduğu sorulduğunda çocuğun nesnenin sahibini parmağı ile göstermesi beklenirken, neden bu kişinin nesnenin sahibi olduğu sorulduğunda bunu sözlü olarak yanıtlaması beklenmiştir. Bu nedenle, mülkiyete dair alınan ölçümler çocukların ifade edici ve alıcı dil becerilerinden ayrı düşünülemez.

\section{TARTIŞMA}

$\mathrm{Bu}$ derleme çalışmasında, erken çocukluk döneminde mülkiyet kavramı gelişimi açıklanmış ve ilişkili olabileceği sosyal-bilişsel değişkenler ele alınmıştır. Yapılan çalışmalar incelendiğinde, iki yaşından itibaren çocukların mülkiyet kavramını anladığına ilişkin bulgular olduğu; ancak yaşa bağlı olarak bu becerinin anlamlı şekilde değiştiği ve geliştiği tespit edilmiştir (Blake ve Harris, 2011; Fasig, 2000; Noles ve Keil, 2011). Araştırmacıların mülkiyetin gelişimi ve boyutlarının belirlenmesinde fikir ayrılığına düştüğü, farklı mülkiyet belirteçlerini araştırmalarına konu aldıkları görülmektedir. Örneğin, kimi araştırmacılar yeni bir nesnenin üretiminde emek verenin mi yoksa nesneye ilk sahip olanın mı mülkiyet hakkına sahip olacağı (örn., ilk sahip yanlılığı; Kanngiesser ve Hood, 2014b) gibi bir açıdan kavrama yaklaşırken; başka araştırmacılar ise meşru olan veya olmayan aktarımlar sonucunda mülkiyet haklarının atfının nasıl yapıldığına odaklanmıştır (örn., mülkiyet aktarımı; Nancekivell ve ark., 2013).

Mülkiyet işlemleri benlik kavramı ve/veya zihinsel temsiller yoluyla açıklanmaya çalışıldığında, bu fenomenin sosyal ve bilişsel açıdan karmaşık yapısı göz önüne serilmektedir. Temel bilgi yaklaşımı gibi bebeğin nesneye dair doğuştan bilgi işleme sistemlerinin mekan algısı, sayı farkındalığı, nesne devamlılığı, dil gibi becerilerden sorumlu olduğunu ve bu bilgi sistemleri sayesinde bebeğin dünya bilgisini oluşturduğunu iddia eden araştırmacılar bulunmaktadır (Spelke ve Kinzler, 2007). Temel bilgi işleme sistemlerinin mülkiyetin varlığını zihinde canlandırmak için elverişli olabileceği düşünülse de Pesowski ve Friedman'ın (2018) da aralarında bulunduğu başka araştırmacılar çocuğun asıl becerisinin nesne ve kişiler arasındaki üçlü ilişkiyi anlaması sayesinde mülkiyete dair kavrayışın mümkün olabildiğini öne sürer. Bu becerinin, evrensel olarak çocuklarda benzer dönemlerde sergilenmeye başlaması, ilişkili olduğu bilişsel beceriler, evrimsel ve türe özgü özelliklerin varlığı mülkiyet kavramına ilişkin yanıtlanması gereken soruların cevabının kolay olmadığını göstermektedir. 
Mülkiyeti yalnızca sosyal bir yapı olarak ele almak mümkün değildir. Çünkü mülkiyet bilişsel bir süreçtir ve zihinsel temsiller, dikkat, bilişsel esneklik, dil gibi farklı kaynaklar sayesinde gerçekleştirilebilen bir mantıksal çıkarım becerisidir. Mülkiyet, nadiren bazı primatlarda görülmekle birlikte, özellikle mülkiyeti sürdürebilme yetisi insanlarda daha baskındır. Mülkiyet anlayışı, bilişsel karmaşıklığımızın veya gelişmiş kültürümüzün bir sonucu olarak insanlarda ortaya çıkmasından kaynaklı olabileceği gibi (Kalish ve Anderson, 2011; Noles ve Keil, 2011), bilişsel karmaşıklıkların diğer bazı türlerde görülen temel mülkiyet veya sahip olma davranışlarının devamı olması da mümkündür. Ancak doğuştancı bir yaklaşım mülkiyet gelişimi üzerindeki bilişsel ve sosyal etkileri en aza indirecektir. Bu nedenle, insanların mülkiyete ilişkin belirli bilişsel yatkınlıkları miras almış olabileceğine dair varsayımlara rağmen (Stake, 2004), mülkiyetin tamamen doğuştan gelen bir yapı olduğunu önermek mümkün görünmeyebilir. Blake ve Harris (2011) doğuştancı bir yaklaşımı reddederek, alternatif bir gelişim modeli sunmuş, bu gelişim modelinde nesne ve insan ilişkilerini merkeze alan bir yaklaşım önermiştir. $\mathrm{Bu}$ yaklaşım mülkiyet gelişiminin diğer bilişsel beceriler ile olan ilişkisine dayanmaktadır. İleride yapılacak araştırmalar, çocuğun mülkiyeti kavrama sürecinde etkisi olabileceği düşünülen bilişsel becerileri de (örn., yürütücü işlevler, zihin kuramı, dil becerileri) ölçerek bu kuramsal çerçeveye veri sağlamalıdır.

Bu derlemede mülkiyet gelişiminin daha çok sosyal-bilişsel beceriler ile ilişkisi incelenmiş, mülkiyet gelişimi bu çerçevede açıklanmaya çalışılmıştır (örn., benlik, zihinsel temsil, dil becerileri). Mevcut derlemenin yazarlarının, alan yazında mülkiyet ile benzer bir bilişsel kaynaktan beslendiğini düşündüğünü yürütücü işlev ve zihin kuramı gibi sosyal-bilişsel becerilerin, otizm spektrumundaki çocuklarda farklı bir gelişimsel örüntü izlediği pek çok kez bildirilmiştir (Gilotty, Kenworthy, Sirian, Black ve Wagner, 2002; Ozonoff, 1997; Peterson ve Siegal, 1999). Nesneye sahip olduğunu bilmek, kişinin nesne ile görünmez, sosyal olarak anlamlı bir ilişki kurmasını sağlar. Bu bilgi, zaman içinde (nesneyle bağlantılı olarak) sürekli olarak benliğin farkındalığını ve sosyal bir yapı olarak sahiplenme anlayışını gerektirir (Fasig, 2000). Ancak otizm spektrumundaki çocukların benliklerine ilişkin anlayışları (self-understanding) ve benlik farkındalıkları (self-awareness) normal gelişen çocuklardan farklıdır (Frith, 2003; Lind, 2010). Benzer şekilde otizmli çocuklar, birinci şahıs zamirlerini kullanmakta güçlük çekmekte (örn., ‘ben’ ve ‘benim'; Lee, Hobson ve Chiat, 1994; Lind ve Bowler, 2009), tipik olarak gelişen çocuklarla karşılaştırıldığında, iyelik zamirlerine dayalı sahip-nesne ilişkile- 
rini takip etmede zorlanmakta ve üçüncü şahsa ait mülkiyeti tespit ederken daha fazla hata yapmaktadır (Hartley, Harrison ve Shaw, 2020b). Bu bulgular, otizmli çocukların, bilgiyi kendiyle ilgili olarak etiketleme becerisinin az olduğunu ve dolayısıyla genişletilmiş bir benlik kavramı geliştirmelerini engellediğini göstermektedir (Lind, 2010). Otizm spektrumundaki çocukların bir oyuncak tercihi olmamasından yola çıkarak araştırmacılar, farklı benlik anlayışı süreçlerinden dolayı otizm spektrumunda sahiplik davranışının azaldığını, nesnenin kime ait olduğundan ziyade maddi niteliğine (örn., bir oyuncağın ne olduğuna) önem veren daha ekonomik-rasyonel bir stratejinin ortaya çıktığını iddia etmektedir (Hartley ve Fisher, 2018). Bununla birlikte, otizmli yetişkinlerle yapılan çalışmadan elde edilen sonuçlar, otizmli olmayan çocukların sonuçlarından farklılaşmış, sahiplik geçmişinin, nesne değerlendirmesinde önemli bir etkisi olduğunu ortaya koymuştur (Hartley ve ark., 2020b). Bu da mülkiyet anlayışına ilişkin çeşitli süreçlerin otizmli bireylerde tamamen yok olmaktan ziyade, gelişimsel olarak gecikebileceği düşüncesini desteklemektedir. Benzer şekilde, yapılan çalışmalarda, otizmli çocukların kendilerinin ve başkalarının mülkiyet haklarını savunma olasılıklarının daha düşük olduğu bulunmuştur (Hartley ve ark., 2020b). Tüm araştırmalar göz önünde bulundurulduğunda, gelecekte otizm spektrumundaki çocuklarla yapılacak başka çalışmaların mülkiyet kavramının daha iyi anlaşılmasına katkı sağlayacağı düşünülebilir.

Mülkiyet kavramını anlamak ve açıklamak için yalnızca yaşa bağlı gelişimi incelemek yeterli değildir. Çok boyutlu bir kavram olan mülkiyetin anlaşılabilmesi için hangi nesnelerin sahiplenilebildiğinin bilinmesi, mülkiyete ilişkin ayrıcalıkların tanınması, mülkiyet aktarımının nasıl gerçekleştirildiğinin ayırt edilebilmesi ve nesnenin bir sahibi olup olmadığının da fark edilmesi gerekir. Ancak bu şekilde bu becerinin kökenlerine ilişkin daha fazla bilgi sahibi olmak mümkün olacaktır. Yapılan çalışmalar (örn., Friedman ve ark., 2011; Neary, Van de Vondervoort ve Friedman, 2012; Wang, Defeyter ve Stabler, 2011), çocukların insan yapımı olan yapay nesneleri, doğal nesnelere kıyasla daha fazla sahiplenilebilir bulduğunu ortaya koymaktadır. Bu sonuç, yalnızca aşina olunan değil, aynı zamanda aşina olmadıkları nesnelerin sunulduğu koşullarda da tekrarlanması nedeniyle oldukça önemlidir. Çünkü çocukların sahip oldukları deneyim ve temsilleri başka koşullara da uyarlayabildiği ve genelleme yapabildiği fikri bu sayede desteklenebilmiştir.

Bir nesneye sahip olmak veya onu kullanmak için öncesinde o nesnenin bir sahibi olup olmadığını bilmek gerekir. Çocuklar, erken yaşlardan itibaren çeşitli ipuçları kulla- 
narak bir nesnenin sahibi olup olmadığını ve eğer var ise sahibini tespit edebilmektedir (Brownell ve ark., 2013; Fasig, 2000; Rodgon ve Rashman, 1976). Ancak bu süreçte sosyal normların önemli bir etkisi olduğu görülmektedir (Nancekivell, Van de Vondervoort ve Friedman, 2013; Neary, Friedman ve Burnstein, 2009). Bu durum çocukların davranışlarının şekillenmesindeki toplumsal etkileri ortaya koymaktadır. Bir kişinin bir nesneye sahip olduğunu bilmenin davranışlar üzerindeki belirleyici etkisini görebilmek için sosyal ilişkilerde ebeveynin nesneleri ilişkiye dahil etmesi ve nesneyi bir araç olarak kullanmasını da anlamak gerekmektedir. Bu kavram ele alınırken göz ardı edilmemesi gereken diğer önemli unsurlar ise kültür ve dil olacaktır. Çocuğa yöneltilen dil onun hem bilişsel becerileri üzerinde belirleyici bir rol oynayacak hem de sosyal olarak çocuğu zenginleştirecektir. Her ne kadar mülkiyet insan doğasının evrensel bir parçası olsa da kültürel öğelerin mülkiyet gelişimi üzerinde belirleyici etkileri anlaşılmalıdır. Dil yapısı ve kullanımı ile mülkiyet gelişimi arasındaki ilişkiyi inceleyen bir çalışmaya rastlanmazken, kültür ile mülkiyet gelişimi arasındaki ilişkiyi inceleyen sınırlı sayıda çalışma olduğu görülmüştür (örn., Li ve ark., 2018). Bu açıdan, bu konuda yapılacak daha fazla çalışmaya ihtiyaç olduğu anlaşılmaktadır. Mülkiyetin Batı kültürlerinde daha yaygın olarak kabul gördüğü ve önemsendiğine dair bir inanış bulunmaktadır (örn., Kanngiesser ve ark., 2015). Bu durumun ekonomik düzenin bir parçası olduğu düşünülebilir. Öte taraftan, daha kolektif, ortak üretim ve tüketim prensibine sahip farklı toplumlar ve kabilelerde mülkiyet anlayışının incelenmesi, bu beceriye ilişkin bilgiyi arttıracaktır. Sosyal ve bilişsel beceriler ile kritik bir ilişki içinde olan mülkiyet kavramının çocuklardaki gelişim süreçlerini incelemek, hem gelişim psikolojisi alan yazınına katkı sağlayacak, hem de çocuklara yönelik eğitim ve psikolojik faaliyetlerin geliştirilmesinde yararlı olacaktır.

\footnotetext{
Hakem Değerlendirmesi: Dış bağımsız.

Yazar Katkıları: Çalışma Konsepti/Tasarım- F.C.P., Z.Ş.H., B.A.; Veri Toplama- F.C.P., Z.Ş.H., B.A.; Veri Analizi/ Yorumlama- F.C.P., Z.Ş.H., B.A.; Yazı Taslağı- F.C.P., Z.Ş.H., B.A.; İçeriğin Eleştirel İncelemesi- F.C.P., Z.Ş.H., B.A.; Son Onay ve Sorumluluk- F.C.P.

Çıkar Çatışması: Yazarlar çıkar çatışması bildirmemiştir.

Finansal Destek: Yazarlar bu çalışma için finansal destek almadığını beyan etmiştir.

Peer-review: Externally peer-reviewed.

Author Contributions: Conception/Design of Study- F.C.P., Z.Ş.H., B.A.; Data Acquisition- F.C.P., Z.Ş.H., B.A.; Data Analysis/Interpretation- F.C.P., Z.Ş.H., B.A.; Drafting Manuscript- F.C.P., Z.Ş.H., B.A.; Critical Revision of Manuscript- F.C.P., Z.Ş.H., B.A.; Final Approval and Accountability- F.C.P.

Conflict of Interest: The authors have no conflict of interest to declare.

Grant Support: The authors declared that this study has received no financial support.
} 


\section{Kaynakça/References}

Aikhenvald, A. Y. (2013). Possession and ownership: A cross-linguistic perspective. A. Y. Aikhenvald ve R. M. W. Dixon (Ed.), Possession and ownership: A cross-linguistic typology içinde (s.1-64). Oxford University Press.

Aksu-Koç, A., Küntay, A. C., Acarlar, F., Maviş, İ., Sofu, H., Topbaş, S. ve Turan, F. (2011). Türkçe'de erken sözcük ve dilbilgisi gelişimini ölçme ve değerlendirme çalışması. Türkçe İletişim Gelişimi Envanterleri: Tige-I ve Tige-II. Tübitak raporu.

Anderson, P. (2002). Assessment and development of executive function (EF) during childhood. Child Neuropsychology, 8(2), 71-82. https://doi.org/10.1076/chin.8.2.71.8724

Astington, J. W. (2003). Sometimes necessary, never sufficient: False-belief understanding and social competence. B. Repacholi ve V. Slaughter (Ed.), Macquarie monographs in cognitive science. Individual differences in theory of mind: Implications for typical and atypical development içinde (s. 13-38). East Sussex: Psychology Press.

Astington, J. W. ve Jenkins, J. M. (1999). A longitudinal study of the relation between language and theory-of-mind development. Developmental Psychology, 35(5), 1311-1320. https://doi. org/10.1037/0012-1649.35.5.1311

Bates, E. (1976). Language and context: The acquisition of pragmatics. New York, NY: Academic Press.

Belk, R. W. (1988). Possessions and the extended self. Journal of Consumer Research, 15(2), 139-168. https://doi.org/10.1086/209154

Belk, R. W. (2000). Materialism and the modern US Christmas. Advertising \& Society Review, 1(1). https://doi.org/10.1353/asr.2000.0001

Blake, P. R., Ganea, P. A. ve Harris, P. L. (2012). Possession is not always the law: With age, preschoolers increasingly use verbal information to identify who owns what. Journal of Experimental Child Psychology, 113(2), 259-272. https://doi.org/10.1016/j.jecp.2012.06.008

Blake, P. R. ve Harris, P. L. (2009). Children's understanding of ownership transfers. Cognitive Development, 24(2), 133-145. https://doi.org/10.1016/j.cogdev.2009.01.002

Blake, P. R. ve Harris, P. L. (2011). Early representations of ownership. H. Ross ve O. Friedman (Ed.), Origins of ownership of property. New directions for child and adolescent development, 132 içinde (s. 39-51). San Francisco: Jossey-Bass. https://doi.org/10.1002/cd.295

Boyer, P. (2015) How natural selection shapes conceptual structure: Human intuitions and concepts of ownership. E. Margolis ve S. Laurence (Ed.) The conceptual mind. New directions in the study of concepts içinde (s.185-200). MIT Press.

Brownell, C. A., Iesue, S. S., Nichols, S. R. ve Svetlova, M. (2013). Mine or yours? Development of sharing in toddlers in relation to ownership understanding. Child Development, 84(3), 906-920. https://doi.org/10.1111/cdev.12009

Butterworth, G. (1990). Self-perception in infancy. D. Cicchetti ve M. Beeghly (Ed.) The self in transition: Infancy to childhood içinde (s.119-137). The University of Chicago Press.

Carlson, S. M. (2005). Developmentally sensitive measures of executive function in preschool children. Developmental Neuropsychology, 28(2), 595-616. https://doi.org/10.1207/ s15326942dn2802_3

Carlson, S. M. ve Moses, L. J. (2001). Individual differences in inhibitory control and children's theory of mind. Child Development, 72(4), 1032-1053. https://doi.org/10.1111/1467-8624.00333

Carpendale, J. I. ve Lewis, C. (2004). Constructing an understanding of mind: The development of children's social understanding within social interaction. Behavioral and Brain Sciences, 27(1), 79-96. https://doi.org/10.1017/S0140525X04000032

Choi, S. ve Gopnik, A. (1995). Early acquisition of verbs in Korean: A cross-linguistic study. Journal of Child Language, 22(3),497-529.https://doi.org/10.1017/S0305000900009934 
Cleroux, A., \& Friedman, O. (2021). Young children infer feelings of ownership from habitual use. Emotion, 21(3), 607-616. https://doi.org/10.1037/emo0000722

Csikszentmihalyi, M. ve Rochberg-Halton, E. (1981). The meaning of things: Domestic symbols and the self. Cambridge University Press.

Cunningham, S. J., Vergunst, F., Macrae, C. N. ve Turk, D. J. (2013). Exploring early self-referential memory effects through ownership. British Journal of Developmental Psychology, 31(3), 289-301. https://doi.org/10.1111/bjdp.12005

Davoodi, T., Nelson, L. J. ve Blake, P. R. (2020). Children's conceptions of ownership for self and other: Categorical ownership versus strength of claim. Child Development, 91(1), 163-178. https:// doi.org/10.1111/cdev. 13163

Diamond, A. (2013). Executive functions. Annual Review of Psychology, 64, 135-168. https://doi. org/10.1146/annurev-psych-113011-143750

Diesendruck, G. ve Perez, R. (2015). Toys are me: Children's extension of self to objects. Cognition, 134, 11-20. https://doi.org/10.1016/j.cognition.2014.09.010

Dittmar, H. (1992). The social psychology of material possessions: To have is to be. New York, NY: St. Martin's Press.

Dixon, S. (2015). Gimme! Gimme! Gimme!: Object requests, ownership and entitlement in a children's play session. Journal of Pragmatics, 82, 39-51. https://doi.org/10.1016/j.pragma.2015.03.009

Dunfield, K., Kuhlmeier, V., O'Connell, L. ve Kelley, E. (2011). Examining the diversity of prosocial behavior: Helping, sharing, and comforting in infancy. Infancy, 16, 227-247. https://doi. org/10.1111/j.1532-7078.2010.00041.x

Dunn, J. ve Munn, P. (1987). Development of justification in disputes with mother and sibling. Developmental Psychology, 23(6), 791-798. https://psycnet.apa.org/doi/10.1037/00121649.23.6.791

Elenbaas, L. (2019). Young children's reasoning about equality and ownership in resource conflicts. Cognitive Development, 52, 1-8. https://doi.org/10.1016/j.cogdev.2019.100808

Fasig, L. G. (2000). Toddlers' understanding of ownership: Implications for self-concept development. Social Development, 9(3), 370-382. https://doi.org/10.1111/1467-9507.00131

Feldman, R. ve Masalha, S. (2010). Parent-child and triadic antecedents of children's social competence: Cultural specificity, shared process. Developmental Psychology, 46(2), 455-467. https://doi.org/10.1037/a0017415

Fenson, L., Marchman, V. A., Thal, D. J., Dale, P. S., Reznick, J. S. ve Bates, E. (2007). MacArthurBates Communicative Development Inventories: User's Guide and Technical Manual. Baltimore, MD: Paul H. Brookes Publishing Co.

Friedman, N. P. ve Miyake, A. (2004). The relations among inhibition and interference control functions: A latent-variable analysis. Journal of Experimental Psychology: General, 133(1), 101-135. https:// doi.org/10.1037/0096-3445.133.1.101

Friedman, O. ve Neary, K. R. (2008). Determining who owns what: Do children infer ownership from first possession? Cognition, 107(3), 829-849. https://doi.org/10.1016/j.cognition.2007.12.002

Friedman, O., Neary, K. R., Defeyter, M. A. ve Malcolm, S. L. (2011). Ownership and object history. H. Ross ve O. Freidman (Ed.) Origins of ownership of property. New directions for child and adolescent development, 132 içinde (s.79-89). San Francisco: Jossey-Bass. https://doi.org/10.1002/ cd. 298

Friedman, O. ve Ross, H. (2011). Twenty-one reasons to care about the psychological basis of ownership. H. Ross ve O. Freidman (Ed.) Origins of ownership of property. New Directions for child and adolescent development, 132 içinde (s.1-8). San Francisco: Jossey-Bass. https://doi. org/10.1002/cd.292 
Frith, U. (2003). Autism: Explaining the enigma (2. bs.). Malden: Blackwell Publishing.

Gelman, S. A. (2009). Learning from others: Children's construction of concepts. Annual Review of Psychology, 60, 115-140. https://doi.org/10.1146/annurev.psych.59.103006.093659

Gelman, S. A. ve Davidson, N. S. (2016). Young children's preference for unique owned objects. Cognition, 155,146-154. https://doi.org/10.1016/j.cognition.2016.06.016

Gelman, S. A., Frazier, B. N., Noles, N. S., Manczak, E. M. ve Stilwell, S. M. (2015). How much are Harry Potter's glasses worth? Children's monetary evaluation of authentic objects. Journal of Cognition and Development, 16(1), 97-117. https://doi.org/10.1080/15248372.2013.815623

Gelman, S. A., Manczak, E. M. ve Noles, N. S. (2012). The nonobvious basis of ownership: Preschool children trace the history and value of owned objects. Child Development, 83(5), 1732-1747. https://doi.org/10.1111/j.1467-8624.2012.01806.x

Gelman, S. A., Martinez, M., Davidson, N. S. ve Noles, N. S. (2018). Developing digital privacy: Children's moral judgments concerning mobile GPS devices. Child Development, 89(1), 17-26. https://doi.org/10.1111/cdev.12826

Gilotty, L., Kenworthy, L., Sirian, L., Black, D. O. ve Wagner, A. E. (2002). Adaptive skills and executive function in autism spectrum disorders. Child Neuropsychology, 8(4), 241-248. https:// doi.org/10.1076/chin.8.4.241.13504

Hardecker, S. ve Tomasello, M. (2017). From imitation to implementation: How two-and three-yearold children learn to enforce social norms. British Journal of Developmental Psychology, 35(2), 237-248. https://doi.org/10.1111/bjdp.12159

Harris, P. L. ve Koenig, M. A. (2006). Trust in testimony: How children learn about science and religion. Child Development, 77(3), 505-524. https://doi.org/10.1111/j.1467-8624.2006.00886.x

Hartley, C. ve Fisher, S. (2018). Mine is better than yours: Investigating the ownership effect in children with autism spectrum disorder and typically developing children. Cognition, 172, 26-36. https:// doi.org/10.1016/j.cognition.2017.11.009

Hartley, C., Fisher, S. ve Fletcher, N. (2020a). Exploring the influence of ownership history on object valuation in typical development and autism. Cognition, 197, 1-19. https://doi.org/10.1016/j. cognition.2020.104187

Hartley, C., Harrison, N. ve Shaw, J. J. (2020b). Does autism affect childrens identification of ownership and defence of ownership rights?. (Yayımlanmamıs Doktora Tezi). Lancaster University, Lancaster, İngiltere.

Hay, D. F. (2006). Yours and mine: Toddlers' talk about possessions with familiar peers. British Journal of Developmental Psychology, 24(1), 39-52. https://doi.org/10.1348/026151005X68880

Hedenbro, M., Shapiro, A. F. ve Gottman, J. M. (2006). Play with me at my speed: Describing differences in the tempo of parent-infant interactions in the Lausanne Triadic Play paradigm in two cultures. Family Process, 45(4), 485-498. https://doi.org/10.1111/j.1545-5300.2006.00184.x

Hood, B. M. ve Bloom, P. (2008). Children prefer certain individuals over perfect duplicates. Cognition, 106, 455-462. https://doi.org/10.1016/j.cognition.2007.01.012

Hood, B., Weltzien, S., Marsh, L. ve Kanngiesser, P. (2016). Picture yourself: Self-focus and the endowment effect in preschool children. Cognition, 152, 70-77. https://doi.org/10.1016/j. cognition.2016.03.019

Hughes, C. ve Ensor, R. (2008). Does executive function matter for preschoolers' behaviors? Journal of Abnormal Child Psychology, 36(1), 1-14. https://doi.org/10.1007/s10802-007-9107-6

James, W. (1890). The principles of psychology. New York, NY: Holt.

Jenkins, J. M. ve Astington, J. W. (2000). Theory of mind and social behavior: Causal models tested in a longitudinal study. Merrill-Palmer Quarterly, 46(2), 203-220. 
Kalish, C. W. ve Anderson, C. D. (2011). Ownership as a social status. New Directions for Child and Adolescent Development, 132, 65-77. https://doi.org/10.1002/cd.297

Kanngiesser, P. ve Hood, B. (2014a). Not by labor alone: Considerations for value influence use of the labor rule in ownership transfers. Cognitive Science, 38(2), 353-366. https://doi.org/10.1111/ cogs. 12095

Kanngiesser, P. ve Hood, B. M. (2014b). Young children's understanding of ownership rights for newly made objects. Cognitive Development, 29, 30-40. https://doi.org/10.1016/j.cogdev.2013.09.003

Kanngiesser, P., Itakura, S. ve Hood, B. M. (2014). The effect of labour on ownership decisions in two cultures: Developmental evidence from Japan and the United Kingdom. British Journal of Developmental Psychology, 32(3), 320-329. https://doi.org/10.1111/bjdp.12043

Kanngiesser, P., Itakura, S., Zhou, Y., Kanda, T., Ishiguro, H. ve Hood, B. (2015). The role of social eyegaze in children's and adults' ownership attributions to robotic agents in three cultures. Interaction Studies, 16(1), 1-28. https://doi.org/10.1075/is.16.1.01kan

Kim, S. ve Kalish, C. W. (2009). Children's ascriptions of property rights with changes of ownership. Cognitive Development, 24(3), 322-336. https://doi.org/10.1016/j.cogdev.2009.03.004

Kozma, R. B., Russell, J., Jones, T., Marx, N. ve Davis, J. (1996). The use of multiple, linked representations to facilitate science understanding. Vosniadou, S., De Corte, E., Glaser, R. ve Mandle, H. (Ed.) International perspectives on the design of technology-supported learning environments içinde (s. 41-59). New York and London: Routledge.

Lagattuta, K. H., Wellman, H. M. ve Flavell, J. H. (1997). Preschoolers' understanding of the link between thinking and feeling: Cognitive cuing and emotional change. Child Development, 68, 1081-1104. https://doi.org/10.2307/1132293

Lee, A., Hobson, R. P. ve Chiat, S. (1994). I, you, me, and autism: An experimental study. Journal of Autism and Developmental Disorders, 24(2), 155-176. https://doi.org/10.1007/bf02172094

Lewis, M. ve Brooks-Gunn, J. (1979). Toward a theory of social cognition: The development of self. New Directions for Child and Adolescent Development, 4(1), 1-20. https://doi.org/10.1002/ cd.23219790403

Lewis, C., Koyasu, M., Oh, S., Ogawa, A., Short, B. ve Huang, Z. (2009). Culture, executive function, and social understanding. C. Lewis ve J. I. M. Carpendale (Ed.) New directions for child and adolescent development- Special Issue: Social Interaction and the Development of Executive Function 123 içinde (s. 69-85). https://doi.org/10.1002/cd.236

Li, V., Shaw, A. ve Olson, K. R. (2013). Ideas versus labor: What do children value in artistic creation? Cognition, 127(1), 38-45. https://doi.org/10.1016/j.cognition.2012.11.001

Li, Z., Qi, M., Yu, J. ve Zhu, L. (2018). Who is the rightful owner? Young children's ownership judgments in different transfer contexts. Frontiers in Psychology, 9, 1314. https://doi.org/10.3389/ fpsyg.2018.01314

Lind, S. E. (2010). Memory and the self in autism: A review and theoretical framework. Autism, 14(5), 430-456. https://doi.org/10.1177/1362361309358700

Lind, S. E. ve Bowler, D. M. (2009). Recognition memory, self-other source memory, and theoryof-mind in children with autism spectrum disorder. Journal of Autism and Developmental Disorders, 39(9), 1231.

Lucas, A. J., Lewis, C., Pala, F. C., Wong, K. ve Berridge, D. (2013). Social-cognitive processes in preschoolers' selective trust: Three cultures compared. Developmental Psychology, 49(3), 579-590. https://doi.org/10.1037/a0029864

Malcolm, S., Defeyter, M. A. ve Friedman, O. (2014). Children and adults use gender and age stereotypes in ownership judgments. Journal of Cognition and Development, 15(1), 123-135. https://doi.org/1 $0.1080 / 15248372.2012 .728545$ 
McDermott, C. H. ve Noles, N. S. (2018). The role of age, theory of mind, and linguistic ability in children's understanding of ownership. PloS One, 13(10), e0206591. https://doi.org/10.1371/ journal.pone.0206591

Meltzoff, A. N. ve Moore, M. K. (1995). A theory of the role of imitation in. The Self in Infancy: Theory and Research, 112 içinde (s.73-93). Amsterdam: Elsevier.

Miyake, A. ve Friedman, N. P. (2012). The nature and organization of individual differences in executive functions: Four general conclusions. Current Directions in Psychological Science, 21(1), 8-14. https://doi.org/10.1177/0963721411429458

Miyake, A., Friedman, N. P., Emerson, M. J., Witzki, A. H., Howerter, A. ve Wager, T. D. (2000). The unity and diversity of executive functions and their contributions to complex "frontal lobe" tasks: A latent variable analysis. Cognitive Psychology, 4l(1), 49-100. https://doi.org/10.1006/ cogp.1999.0734

Morewedge, C. K. ve Giblin, C. E. (2015). Explanations of the endowment effect: An integrative review. Trends in Cognitive Sciences, 19(6), 339-348. https://doi.org/10.1016/j.tics.2015.04.004

Naito, M. ve Koyama, K. (2006). The development of false-belief understanding in Japanese children: Delay and difference? International Journal of Behavioral Development, 30, 290-304. doi:10.1177/0165025406063622

Nancekivell, S. E., Friedman, O. ve Gelman, S. A. (2019). Ownership matters: People possess a naïve theory of ownership. Trends in Cognitive Sciences, 23(2), 102-113. https://doi.org/10.1016/j. tics.2018.11.008

Nancekivell, S. E., Van de Vondervoort, J. W. ve Friedman, O. (2013). Young children's understanding of ownership. Child Development Perspectives, 7(4), 243-247. https://doi.org/10.1111/cdep.12049

Neary, K. R., Friedman, O. ve Burnstein, C. L. (2009). Preschoolers infer ownership from "control of permission." Developmental Psychology, 45, 873-876. doi:10.1037/a0014088

Neary, K. R., Van de Vondervoort, J. W. ve Friedman, O. (2012). Artifacts and natural kinds: Children's judgments about whether objects are owned. Developmental Psychology, 48(1), 149-158. https:// doi.org/10.1037/a0025661

Neisser, U. (1988). Five kinds of self-knowledge. Philosophical Psychology, 1(1), 35-59. https://doi. org/10.1080/09515088808572924

Noles, N. S. ve Keil, F. C. (2011). Exploring ownership in a developmental context. New Directions for Child and Adolescent Development, 132, 91-103. https://doi.org/10.1002/cd.299

Olson, K. R. ve Shaw, A. (2011). 'No fair, copycat!': What children's response to plagiarism tells us about their understanding of ideas. Developmental Science, 14(2), 431-439. https://doi.org/10.1111/ j.1467-7687.2010.00993.x

Ozonoff, S. (1997). Components of executive function in autism and other disorders. Russell, J. (Ed.), Autism as an executive disorder içinde (s.179-211). Oxford University Press.

Perner, J., Lang, B. ve Kloo, D. (2002). Theory of mind and self-control: More than a common problem of inhibition. Child Development, 73(3), 752-767. https://doi.org/10.1111/1467-8624.00436

Pesowski, M. L. ve Friedman, O. (2018). Using versus liking: Young children use ownership to predict actions but not to infer preferences. Journal of Experimental Child Psychology, 169, 19-29. https:// doi.org/10.1016/j.jecp.2017.12.007

Peterson, C.C. ve Siegal, M. (1999). representing inner worlds: theory of mind in autistic, deaf, and normal hearing children. Psychological Science, 10(2) 126-129. doi:10.1111/1467-9280.00119

Piaget, J. (1945/1995). Logical operations and social life. J. Piaget (Ed.), Sociological studies içinde (s. 134-157). New York: Routledge. 
Pietraszewski, D. ve Shaw, A. (2015). Not by strength alone. Human Nature, 26(1), 44-72. https://doi. org/10.1007/s12110-015-9220-0

Pruett, K. D. (1999). Me, myself and I: How children build their sense of self. 18 to 36 months. Goddard Parenting Guides. Goddard Press: New York.

Possessive. (2021). Wikipedia. https://en.wikipedia.org/wiki/Possessive

Rakoczy, H. ve Schmidt, M. F. (2013). The early ontogeny of social norms. Child Development Perspectives, 7(1), 17-21. https://doi.org/10.1111/cdep.12010

Reb, J. ve Connolly, T. (2007). Possession, feelings of ownership, and the endowment effect. Judgment and Decision Making, 2(2), 107. Erişim adresi: https://ink.library.smu.edu.sg/lkcsb_research/2664

Redfoot, D. L. ve Back, K. W. (1988). The perceptual presence of the life course. The International Journal of Aging and Human Development, 27(3), 155-170. https://doi.org/10.2190/8UFW-R1NHF2V1-6R0M

Rochat, P. (2003). Five levels of self-awareness as they unfold early in life. Consciousness and Cognition, 12(4), 717-731. https://doi.org/10.1016/S1053-8100(03)00081-3

Rochat, P. (2010). The innate sense of the body develops to become a public affair by 2-3years. Neuropsychologia, 48(3),738-745.https://doi.org/10.1016/j.neuropsychologia.2009.11.021

Rochat, P. (2011). Possession and morality in early development. H. Ross ve O. Friedman (Ed.), Origins of ownership of property. New directions for child and adolescent development development, 132 içinde (s. 23-38). San Francisco: Jossey-Bass. https://doi.org/10.1002/cd.294

Rodgon, M. M. ve Rashman, S. E. (1976). Expression of owner-owned relationships among holophrastic 14 and 32-month-old children. Child Development, 47, 1219-1222. https://doi.org/10.2307/1128470

Ross, H. S. (1996). Negotiating principles of entitlement in sibling property disputes. Developmental Psychology, 32(1), 90. https://doi.org/10.1037/0012-1649.32.3.560

Ross, H. S. (2013). Effects of ownership rights on conflicts between toddler peers. Infancy, 18(2), 256-275. https://doi.org/10.1111/j.1532-7078.2012.00121.x

Ross, H. S., Friedman, O. ve Field, A. (2015). Toddlers assert and acknowledge ownership rights. Social Development, 24(2), 341-356. https://doi.org/10.1111/sode.12101

Rossano, F., Rakoczy, H. ve Tomasello, M. (2011). Young children's understanding of violations of property rights. Cognition, 121(2), 219-227. https://doi.org/10.1016/j.cognition.2011.06.007

Sartre, J. P. (1956/2021). Varlık ve Hiçlik: Fenomenolojik Ontoloji Denemesi, İthaki Yayınları: İstanbul.

Shi, Z., Zhou, A., Han, W. ve Liu, P. (2011). Effects of ownership expressed by the first-person possessive pronoun. Consciousness and Cognition, 20(3), 951-955. https://doi.org/10.1016/j. concog.2010.12.008

Spelke, E. S., ve Kinzler, K. D. (2007). Core knowledge. Developmental Science, 10(1), 89-96.

Svetlova, M., Nichols, S. R. ve Brownell, C. A. (2010). Toddlers' prosocial behavior: From instrumental to empathic to altruistic helping. Child Development, 81(6), 1814-1827. https://doi.org/10.1111/ j.1467-8624.2010.01512.x

Tardif, T. (1996). Nouns are not always learned before verbs: Evidence from Mandarin speakers' early vocabularies. Developmental Psychology, 32(3), 492-504. https://doi.org/10.1037/00121649.32.3.492

Thaler, R., (1980). Toward a positive theory of consumer choice. Journal of Economic Behavior and Organization, 1, 39-60. https://doi.org/10.1016/0167-2681(80)90051-7

Tisak, M. S. ve Ford, M. E. (1986). Children's conceptions of interpersonal events. Merrill-Palmer Quarterly, 32(3), 291-306.

Wang, J., Defeyter, M. A. G., ve Stabler, R. (2011). Object-context affects 5-to-6-year-olds' and adults' ownership reasoning about artifacts and natural kinds. http://nrl.northumbria.ac.uk/id/eprint/5490/1/ Wang\%20Defeyter\%20Stabler\%202011\%20BPS\%20Dev.pdf Erişim tarihi: 18.05.2021 
Welch-Ross, M. (2001). Personalizing the temporally extended self: Evaluative self-awareness and the development of autobiographical memory. C. Moore \& K. Lemmon (Ed.), The self in time: Developmental perspectives içinde (s. 97-120). Lawrence Erlbaum Associates Publishers.

Winnicott, D. W. (1953). Transitional objects and transitional phenomena: A study of the first not-me possession. International Journal of Psycho-Analysis, 34, 89-97.

Yang, F., Shaw, A., Garduno, E. ve Olson, K. R. (2014). No one likes a copycat: A cross-cultural investigation of children's response to plagiarism. Journal of Experimental Child Psychology, 121, 111-119. https://doi.org/10.1016/j.jecp.2013.11.008

Zelazo, P. D. ve Müller, U. (2002). The balance beam in the balance: Reflections on rules, relational complexity, and developmental processes. Journal of Experimental Child Psychology, 81(4), 458465. https://doi.org/10.1006/jecp.2002.2667 
